Review

\title{
Non-Conventional Deformations: Materials and Actuation
}

\author{
Bruno Vermes ${ }^{1,2}$ and Tibor Czigany ${ }^{1,2, *(1)}$ \\ 1 Department of Polymer Engineering, Faculty of Mechanical Engineering, Budapest University of Technology \\ and Economics, Múegyetem rkp. 3., H-1111 Budapest, Hungary; vermesb@pt.bme.hu \\ 2 MTA-BME Research Group for Composite Science and Technology, Múegyetem rkp. 3., \\ H-1111 Budapest, Hungary \\ * Correspondence: czigany@eik.bme.hu
}

Received: 21 January 2020; Accepted: 13 March 2020; Published: 18 March 2020

check for updates

\begin{abstract}
This paper reviews materials and structures displaying non-conventional deformations as a response to different actuations (e.g., electricity, heat and mechanical loading). Due to the various kinds of actuation and targeted irregular deformation modes, the approaches in the literature show great diversity. Methods are systematized and tabulated based on the nature of actuation. Electrically and mechanically actuated shape changing concepts are discussed individually for their significance, while systems actuated by heat, pressure, light and chemicals are condensed in a shared section presenting examples and main research trends. Besides scientific research results, this paper features examples of real-world applicability of shape changing materials, highlighting their industrial value.
\end{abstract}

Keywords: morphing; shape adaptation; coupling; composites

\section{Introduction}

Making materials multifunctional by endowing them with additional features, such as self-healing [1,2] or integrated health monitoring [3,4] is one of the greatest endeavors of today's material science. The additional feature can also be a special mechanical behavior: morphing. Materials that change shape non-conventionally (morphing materials) allow us to design and manufacture structures that work more efficiently than their conventional counterparts, therefore their research and development are of primary importance for not only academia but industry as well (e.g., the energy and transportation industries). By definition, in this paper, conventional deformations are induced by loads of the same kind as the deformation itself (e.g., extension in response to tensile loading or bending in response to bending moments). Hence, non-conventional deformations are induced by dissimilar loads (e.g., bending in response to tensile loading or twisting in response to bending moment) or actuated by means other than mechanical loading (e.g., deformation to electricity, heat, pressure, etc.)

There is a wide variety of morphing concepts in the literature, and they can be categorized by a number of principles. The main sorting principle of this paper is the type of actuation that is needed for the shape change to take place. The most common means of actuating shape changes are electricity, heat, pressure, light, chemicals and mechanical loads. These concepts can be further categorized as active, semi-active and passive, depending on the extent of human (active) and environmental (passive) influence. There are no clear boundaries between these categories, although electricity is more a kind of active actuation as it can be controlled almost independently of operating conditions, while mechanical loading is set by the operating conditions in the case of a structural part. Heat is a semi-active actuation, being greatly dependent on the environment but very artificially controllable at the same time. 
The optimal shape-changing concept always depends on the application. In some cases, we do not want the material to adapt to its environment; instead, we wish to control its deformation actively. In these cases, systems actuated by electricity [5], heat [6] or pressure [7] may be considered. On the other hand, there are situations when environmental adaptation is what we are after to achieve maximum working efficiency of a structural part. In the case of marine or wind turbine blades, for instance, their shape for optimal energy yield depends on the direction and speed of the flowing fluid, i.e., the mechanical loading the blades are subjected to [8]. A mechanically actuated shape-changing material could passively modulate its shape (e.g., twisting) in response to changing loads (e.g., bending moments), resulting in significant efficiency gains.

This review aims to introduce some selected shape-changing concepts from the literature categorized by the type of actuation giving an up-to-date overview of this field of research.

\section{Electro-Actuated Shape Adaptation}

In this review, electro-actuated shape adaptation is defined as controlled deformation or resistance to deformation in response to applied electricity. Electricity is relatively easily controllable independently of environmental conditions and can be exploited to actuate non-conventional deformation in various ways. It can power electromotors [9-13] as well as piezo- [14-19] and other electrosensitive materials. Due to this diversity, there is an extensive literature on electro-actuated systems. This section discusses some selected concepts.

Electric motors are widely used in motorsport, and industries like the transportation or the aerospace industry, although seldom for morphing applications. The aerospace industry shows the greatest interest in motor-actuated morphing concepts. In a broad sense, conventional wing flaps are morphing structures themselves; however, there are concepts where the triggered deformation is less evident, therefore they are more easily categorized as morphing structures. Garcia et al. [9] designed a micro air vehicle in which torque rods placed along the flexible membrane wings and connected to a servo motor were responsible for control authority by operating roll maneuvers. Stanford et al. [10] investigated a similar structure with asymmetric twisting of the wings with the addition of numerical (static structural and aerodynamic) modelling and genetic algorithm-based optimization. With these tools, they developed a design that showed significantly improved roll-rate and lift-to-drag ratio compared to their baseline design, highlighting the importance of computer-aided optimization, even in the case of simple mechanism actuated systems. Ahmed et al. [20] introduced an aerodynamic optimization process to find the optimal anti-symmetric wing twist distribution of a micro air vehicle (MAV) to achieve improved roll performance together with a low level of produced drag. Their optimization tool showed a rapid convergence to the optimal solution for wing twist design. Motors can be used to achieve deformations other than twisting, too. Boria et al. [11] used genetic algorithm-based hardware-in-the-loop optimization for camber morphing of a composite wing skin actuated by a single servo motor. A system like this can significantly modify the camber and therefore the aerodynamic characteristics and efficiency of the wing with relatively little effort. The effort needed for shape adaptation can also be decreased by altering the mechanical properties of the material for the duration of the deformation. Hamilton et al. [12] reduced the stiffness of the matrix material with a temperature controller by heating it up for the morphing phase and then increased its stiffness by cooling the material back to preserve the new shape. Hybrid approaches like this may require multiple actuation systems, but their energy efficiency or the achievable greater deformations can justify their use in many cases. Another way to increase efficiency is to decrease the number of actuators (motors) needed for complex morphing. Winstone et al. [13] proposed a design of a single-motor-driven worm robot that was capable of peristaltic locomotion thanks to the design of its segments enabling complex motions to simple impulsions.

Besides electromotors, electricity can be exploited for morphing applications with materials that are electrically responsive themselves. Piezoelectric materials are one of the most researched electroresponsive materials as they reliably convert electrical energy into mechanical energy and vice 
versa [14]. Although they generally exhibit relatively low actuation strains, their high force output, even at high frequencies, makes them good candidates for not only vibration dampening but also as actuators to alter the shape of attached materials. Furthermore, Fichera et al. [15] showed that with proper design, deflections can be significant, too, without sacrificing the frequency of response. Yoon et al. [16] developed a camber morphing control fin with integrated piezo-composite actuators in its skin. These structures are generally actuated by a servo motor, but piezo-actuation can simplify the structure; there is no need to convert rotational motion to linear actuation. However, piezo-actuators increase the weight of the morphing structure. For the best weight-to-performance ratio, the optimal number and size of actuators need to be used for a certain application. These can be found by numerical optimization [17]. Jodin et al. [18] investigated a hybrid system, where the camber of a wing was altered by shape memory alloys (SMAs), while trailing edge vibrations were controlled by piezo-actuators, providing some aerodynamic benefit over a static trailing edge. In complex morphing structures, piezo-materials are often complemented by other means of actuation for multifunctionality. Bye et al. [19], for instance, designed a morphing airplane that can significantly change the shape of its wings to adapt to different flight scenarios (e.g., cruising or high-speed dash), for which they employed thermopolymers and shape memory polymers (SMPs) besides piezo-actuators. Nabawy et al. [21,22] developed a comprehensive analytical model to provide a mapping between force, displacement, charge and voltage for piezoelectric actuators. They also validated the model against experimental results. The significance of their work lies in making the performance of piezoelectric actuators predictable in dynamic operations and analyzing the dynamic electromechanical coupling factor, which defines the exchanged electrical and mechanical energy in a single piezoelectric flexure cycle. Based on these results, the applicability of piezoelectric actuators can be assessed for different use cases (e.g., morphing or flapping wings).

Electroactive polymers usually have the advantage of being flexible, lightweight and relatively easy and inexpensive to manufacture. Dielectric elastomer actuators (DEAs) work by the principle of having a flexible membrane between two electrodes that are squeezed together by the Coulomb force when placed under high voltage current. DEAs can demonstrate large strains of a few thousand percent [23], but they can be electromechanically unstable. Kornbluh et al. [24] achieved strains exceeding 200\% with response speeds up to $2000 \mathrm{~Hz}$ with DEAs. Duduta et al. [25] proposed a DEA system with carbon nanotube electrodes to increase the peak energy density to similar levels as the energy density of human muscles, overcoming one of the main limitations of this approach. Ferroelectric polymers change their polar state in response to the applied electric field, and this causes strain, but their energy density is relatively low. Nevertheless, these polymers can be incorporated into nanogenerators for energy harvesting [26].

The working principle of electro-bonded materials is that instead of a permanent, constant adhesion between the constitutive layers, the strength of the interlaminar connection is a function of the applied voltage (Figure 1). Instead of deforming the material, electricity makes the bending stiffness of the structure reversibly variable, therefore controlling its deformation when loaded. Heath et al. [27] more than doubled the bending stiffness of a sandwich structure by electro-bonding the two halves of the core material with $4 \mathrm{kV}$. Bergamini et al. [28] achieved an 18-fold increase in bending stiffness with a similar approach. Heath et al. [29] also investigated interlocking electro-bonded layers where the interfaces were not plain but followed a cosine wave form. This way they achieved direction-dependent variable stiffness. Testoni et al. [30] proposed a concept similar to the previously mentioned electro-bonded approaches but with a twist. They placed truss-like mechanical switches between composite skins as the core material that had a threshold in their actuation power (for axial sliding) when electricity was applied thereby modifying the mechanical behavior of the loaded sandwich structure. 


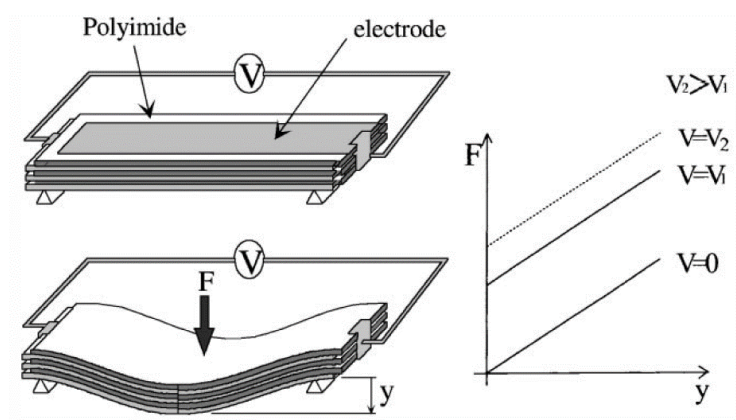

Figure 1. Electro-bonded laminate working principle [31].

Conjugated polymers can be made electrical conductors by a process called "doping" when the molecule is oxidized or reduced. Voltage can change their oxidation state leading to dimensional changes. Advantages include light weight, low actuation energy and relatively high energy density. Polyaniline [32] and polypyrrole [33] are the most researched conjugated polymers for morphing applications, primarily due to their significant strains to an applied voltage. Figure 2 illustrates the schematic of a bi- and a trilayer polyaniline coated electroactive paper actuator [32].

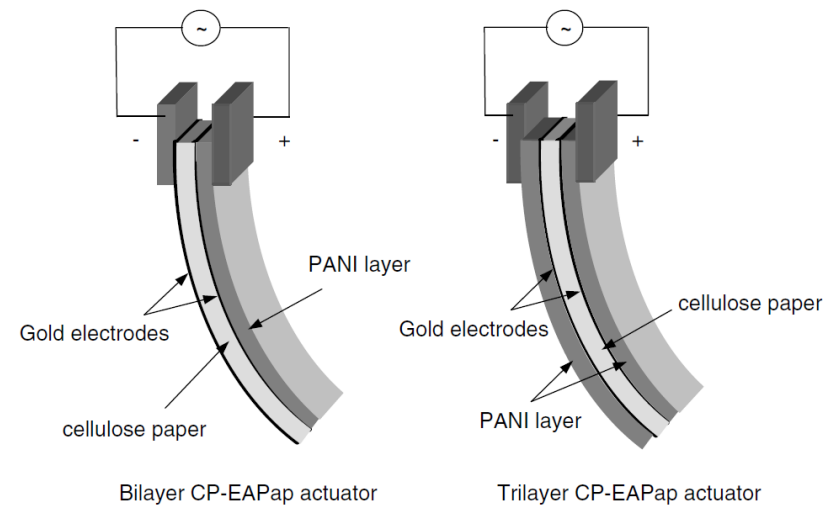

Figure 2. Bi- and trilayer polyaniline coated electroactive paper actuators [32].

Not only solid-state materials can demonstrate deformation to electricity, but gels and fluids, too. Ionic gels can usually deform (bend) significantly in response to low actuation voltages due to counter-ion osmotic pressure. Various types of ionic gels exist, but Bucky-gels are among the most advanced ones as they can operate without an external ionic solution. In response to voltage, anions and cations from the internal polymeric electrolyte film separate and move towards the opposite electrodes. As the two different ions differ in size too, they occupy unequal space near the outer layers leading to an internal pressure difference and therefore the bending of the material [34]. A limitation of the concept is the back-relaxation even when voltage is maintained [35]. Non-ionic gels exist too and can behave similarly to how ionic gels do (e.g., quick, large deformations), but they require much higher actuation voltages [36]. Some hydrogels can even demonstrate bidirectional bending behavior [37]. Electrorheological fluids can change their viscosity in response to applied electricity by forming oriented chains of dielectric particles in an insulating fluid. The application of this easily controllable system varies from stroke rehabilitation robots in medicine [38] to active suspension systems in transportation [39].

Other electro-actuated morphing concepts exist as well, such as electro-origami systems consisting of simple electrodes, an insulator and a liquid dielectric that are capable of muscle-like mechanical performance in response to applied electricity [40].

Table 1 contains some important data about selected electro-actuated morphing systems. Modelling and experimental results are compared in the table only where they significantly differed. This approach applies to each table in the paper. 
Table 1. Electro-actuated morphing systems.

\begin{tabular}{|c|c|c|c|c|c|c|}
\hline Working Principle & $\begin{array}{c}\text { Deforming } \\
\text { Material/Structure }\end{array}$ & Deformation Mode & Testing & Modelling & $\begin{array}{l}\text { Measurement Results, } \\
\text { Comments }\end{array}$ & Reference \\
\hline $\begin{array}{l}\text { Torque rods connected to } \\
\text { servo motor }\end{array}$ & $\begin{array}{l}\text { Flexible membrane } \\
\text { wing }\end{array}$ & Twist & Flight tests: roll control & $\begin{array}{l}\text { Linear time-domain model } \\
\text { approximated from flight } \\
\text { data }\end{array}$ & $\begin{array}{l}\text { Good vehicle controllability: } \\
\text { roll maneuvers carried out by } \\
\text { morphing (primarily). }\end{array}$ & [9] \\
\hline $\begin{array}{l}\text { Torque rods connected to } \\
\text { servo motor }\end{array}$ & $\begin{array}{l}\text { Flexible membrane } \\
\text { wing }\end{array}$ & Twist & $\begin{array}{l}\text { Wind-tunnel and flight tests: roll } \\
\text { control. }\end{array}$ & $\begin{array}{c}\text { Numerical model } \\
\text { (structural and } \\
\text { aerodynamic) and genetic } \\
\text { algorithm-based } \\
\text { optimization for improved } \\
\text { roll control. Good } \\
\text { correlation with test results. }\end{array}$ & $\begin{array}{l}34 \% \text { wing maneuverability and } \\
6 \% \text { wing efficiency } \\
\text { improvement over baseline, } \\
\text { but there is a trade-off between } \\
\text { the two properties. }\end{array}$ & [10] \\
\hline $\begin{array}{l}\text { Servo motor moving loading } \\
\text { rod up and down }\end{array}$ & $\begin{array}{l}\text { Carbon fiber } \\
\text { reinforced wing skin }\end{array}$ & Camber & $\begin{array}{l}\text { Genetic algorithm-aided wind-tunnel } \\
\text { tests: camber-lift relationship. } \\
3 \text { attachments to skin: two fixed } \\
\text { attachments and a motorized } \\
\text { attachment in between. }\end{array}$ & $\begin{array}{l}\text { Hardware-in-the-loop } \\
\text { optimization (see testing). }\end{array}$ & $\begin{array}{l}\text { Optimized wing camber for } \\
\text { maximum lift or efficiency by } \\
\text { means of morphing actuated } \\
\text { by a single servo motor. }\end{array}$ & [11] \\
\hline $\begin{array}{l}\text { Electromotor shears pivotally } \\
\text { connected bars }\end{array}$ & $\begin{array}{l}\text { Pivotally connected } \\
\text { bars (in a rectangular } \\
\text { layout) with fiber } \\
\text { mesh and matrix } \\
\text { material enclosed }\end{array}$ & $\begin{array}{l}\text { In-plane shearing (not } \\
\text { exclusively) }\end{array}$ & $\begin{array}{l}\text { Temperature controller changes the } \\
\text { elastic properties of the matrix (heating } \\
\text { softens the matrix) and then the motor } \\
\text { deforms the structure. Shape is } \\
\text { stabilized by subsequent cooling. }\end{array}$ & - & $\begin{array}{l}\text { Improved airfoil adaptability } \\
\text { for better efficiency by } \\
\text { significantly changing its shape } \\
\text { and size. }\end{array}$ & [12] \\
\hline $\begin{array}{l}\text { Single electromotor drives } \\
\text { complex motions of } \\
\text { connected segments }\end{array}$ & $\begin{array}{l}\text { Segments consisting } \\
\text { of solid circular disks, } \\
\text { Bowden cables and } \\
\text { soft rubber skin }\end{array}$ & Peristaltic locomotion & $\begin{array}{c}3 \text { segments controlled by a single } \\
\text { motor. } 3 \text { tests: moving on flat floor, } \\
\text { and through a tunnel with or without } \\
\text { a payload }\end{array}$ & $\begin{array}{l}\text { Analytical calculations to } \\
\text { translate motor rotation to } \\
\text { linear movement of } \\
\text { Bowden6 cables }\end{array}$ & $\begin{array}{l}\text { Comparable peristaltic } \\
\text { locomotion results to a worm } \\
\text { robot with multiple actuators. }\end{array}$ & [13] \\
\hline $\begin{array}{l}\text { Piezoelectric actuation } \\
\text { integrated in sandwich wing } \\
\text { structure }\end{array}$ & $\begin{array}{l}\text { Sandwich structure of } \\
\text { a wing trailing edge }\end{array}$ & Camber & $\begin{array}{l}\text { Static deflection and load test; } \\
\text { dynamic actuation test }\end{array}$ & $\begin{array}{l}\text { 3D finite element model } \\
\text { with piezo behavior }\end{array}$ & $\begin{array}{c}25 \mathrm{~Hz} \text { bandwidth and } \pm 15^{\circ} \\
\text { deflection }\end{array}$ & [15] \\
\hline $\begin{array}{l}\text { Piezo-composite actuator } \\
\text { integrated in wing structure }\end{array}$ & Glass-epoxy skin & $\begin{array}{l}\text { Camber/pitch rotation } \\
\text { angle }\end{array}$ & $\begin{array}{l}\text { High voltage current on } \\
2 \text { actuators for camber morphing and } 1 \\
\text { actuator for rotation }\end{array}$ & $\begin{array}{l}\text { Analytical rotation and } \\
\text { bending angle, curvature } \\
\text { and bending stiffness } \\
\text { calculations. Greater } \\
\text { predicted } \\
\text { deformation-nonlinearity } \\
\text { as a function of excitation } \\
\text { voltage than test results, } \\
\text { but close values. }\end{array}$ & $\begin{array}{c}450 \mathrm{~V}: \\
1.4^{\circ} \text { camber } \\
5.4^{\circ} \text { pitch rotation angle }\end{array}$ & [16] \\
\hline
\end{tabular}


Table 1. Cont

\begin{tabular}{|c|c|c|c|c|c|c|}
\hline Working Principle & $\begin{array}{c}\text { Deforming } \\
\text { Material/Structure }\end{array}$ & Deformation Mode & Testing & Modelling & $\begin{array}{l}\text { Measurement Results, } \\
\text { Comments }\end{array}$ & Reference \\
\hline $\begin{array}{l}\text { Piezoelectric actuator } \\
\text { integrated in wing structure }\end{array}$ & $\begin{array}{l}\text { Carbon and glass } \\
\text { fiber composite skin }\end{array}$ & Camber & - & $\begin{array}{l}\text { Numerical aeroelastic } \\
\text { (structural and } \\
\text { aerodynamic) optimization }\end{array}$ & $\begin{array}{l}\text { Up to 1100V: } \\
\text { Optimized actuator-skin } \\
\text { thickness ratio for maximum } \\
\text { roll control and minimum } \\
\text { weight. Piezo actuators } \\
\text { provide not only energy for } \\
\text { morphing but stiffness for the } \\
\text { skin, too. }\end{array}$ & [17] \\
\hline $\begin{array}{l}\text { Piezoelectric actuator for } \\
\text { vibration (and shape memory } \\
\text { alloy for static deformation) }\end{array}$ & $\begin{array}{l}\text { A section of a wing } \\
\text { structure with } \\
\text { integrated actuators }\end{array}$ & $\begin{array}{l}\text { High-frequency } \\
\text { vibration (piezo) and } \\
\text { static camber (shape } \\
\text { memory alloy) }\end{array}$ & $\begin{array}{l}\text { Wind-tunnel testing: drag and lift } \\
\text { measurements for more than } 3000 \\
\text { configurations }\end{array}$ & $\begin{array}{l}\text { 2D finite element model for } \\
\text { vibration frequency and } \\
\text { static displacement }\end{array}$ & $\begin{array}{c}\text { Wind tunnel tests: lift-to-drag } \\
\text { ratio improved by } 16 \% \text { because } \\
\text { camber and vibrating trailing } \\
\text { edge improved drag and lift by } \\
\text { a few percent. }\end{array}$ & [18] \\
\hline $\begin{array}{l}\text { Piezoelectric actuation (with } \\
\text { thermopolymer and shape } \\
\text { memory polymers) }\end{array}$ & Elastomer wing skin & Folding/sweeping & $\begin{array}{l}\text { Full-scale subcomponent tests for each } \\
\text { type of actuators }\end{array}$ & $\begin{array}{l}\text { Finite element analysis (to } \\
\text { evaluate drag) }\end{array}$ & $\begin{array}{l}\text { Significantly modifiable } \\
\text { wingspan and wing area } \\
\text { during flight making the plane } \\
\text { suitable for multiple purposes } \\
\text { (e.g., cruising or high-speed } \\
\text { dash) }\end{array}$ & [19] \\
\hline $\begin{array}{l}\text { Dielectric elastomer actuator } \\
\text { (DEA) }\end{array}$ & $\begin{array}{l}\text { Elastomeric polymer } \\
\text { film }\end{array}$ & $\begin{array}{l}\text { Compressed } \\
\text { thickness-expanded } \\
\text { area }\end{array}$ & $\begin{array}{l}\text { Films coated with electrode material } \\
\text { on both sides—electrostatic field } \\
\text { compresses material }\end{array}$ & $\begin{array}{l}\text { Analytical model—effective } \\
\text { pressure derived from } \\
\text { voltage }\end{array}$ & $\begin{array}{c}\text { Silicone elastomers: } \\
117 \% \text { strain } \\
\text { Acrylic elastomers: } 215 \% \text { strain } \\
\text { Good energy efficiency (more } \\
\text { than } 80 \% \text { ) and swift response } \\
\text { speeds (up to } 2000 \mathrm{~Hz} \text { ) }\end{array}$ & [24] \\
\hline $\begin{array}{l}\text { Dielectric elastomer actuator } \\
\text { (DEA) }\end{array}$ & $\begin{array}{c}\text { Acrylic elastomer } \\
\text { with carbon nanotube } \\
\text { electrodes }\end{array}$ & Contraction & $\begin{array}{l}\text { Weight on relaxed actuator. When the } \\
\text { electric current is applied, the actuator } \\
\text { contracts and lifts the weight. }\end{array}$ & $\begin{array}{l}\text { Energy density-electric } \\
\text { field function agrees with } \\
\text { experimental results. }\end{array}$ & $\begin{array}{l}\text { Measured energy density ( } 19.8 \\
\mathrm{~J} / \mathrm{kg} \text { in response to } 3.5 \mathrm{kV}) \text { close } \\
\text { to maximum human muscle } \\
\text { potential. }\end{array}$ & [25] \\
\hline Electrostatic adhesion & $\begin{array}{l}\text { CFRP sandwich with } \\
\text { PVC core }\end{array}$ & Bending (resistance) & $\begin{array}{c}\text { High-voltage current on } \\
\text { copper-polyimide electrodes placed } \\
\text { between the split halves of the PVC } \\
\text { core. }\end{array}$ & $\begin{array}{l}\text { Analytical calculations and } \\
\text { numerical modelling }\end{array}$ & $\begin{array}{l}4 \mathrm{kV} \text { voltage applied: } 112 \% \\
\text { increase in bending stiffness for } \\
\text { the sandwich test specimen }\end{array}$ & [27] \\
\hline Electrostatic adhesion & $\begin{array}{l}\text { CFRP sandwich with } \\
\text { carbon-filled rubber } \\
\text { core }\end{array}$ & Bending (resistance) & $\begin{array}{l}\text { Quasistatic cantilever bending test } \\
\text { where bending stiffness was } \\
\text { modifiable by the electricity applied }\end{array}$ & $\begin{array}{l}\text { Analytical model based on } \\
\text { solid-solid friction } \\
\text { interaction }\end{array}$ & $\begin{array}{l}\text { 18-fold change in bending } \\
\text { stiffness }\end{array}$ & [28] \\
\hline
\end{tabular}


Table 1. Cont

\begin{tabular}{|c|c|c|c|c|c|c|}
\hline Working Principle & $\begin{array}{c}\text { Deforming } \\
\text { Material/Structure }\end{array}$ & Deformation Mode & Testing & Modelling & $\begin{array}{l}\text { Measurement Results, } \\
\text { Comments }\end{array}$ & Reference \\
\hline Electrostatic adhesion & $\begin{array}{l}\text { Polyurethane core } \\
\text { with interlocking } \\
\text { (cosine wave form) } \\
\text { copper-polyimide } \\
\text { electrodes between } \\
\text { the core halves }\end{array}$ & $\begin{array}{l}\text { Change in shear force } \\
\text { (and therefore } \\
\text { bending stiffness) }\end{array}$ & Shear test & - & $\begin{array}{l}\text { The reversible adhesion for } \\
\text { non-planar electro-bonded } \\
\text { laminates is similar to the } \\
\text { simple, planar ones (about } 7-10 \\
\mathrm{kPa} \text { shear stress before slipping } \\
\text { at } 2 \mathrm{kV} \text { ) with the added benefit } \\
\text { of anisotropy due to the } \\
\text { orientation of the electrode }\end{array}$ & [29] \\
\hline Electric mechanical switches & $\begin{array}{l}\text { Sandwich structure } \\
\text { with truss core where } \\
\text { the trusses are } \\
\text { mechanical switches }\end{array}$ & $\begin{array}{l}\text { Change in thickness, } \\
\text { transverse shear and } \\
\text { bending }\end{array}$ & $\begin{array}{l}\text { Tensile tests (internal shearing) of an } \\
\text { individual mechanical switch. }\end{array}$ & $\begin{array}{l}\text { Analytical shear strength } \\
\text { calculations. } \\
\text { Calculated maximum } \\
\text { transferable force is one } \\
\text { order of magnitude higher } \\
\text { than the measured force. }\end{array}$ & $\begin{array}{l}\text { 2000V: } 1.3 \mathrm{~N} \text { measured } \\
\text { threshold force before the } \\
\text { aluminum electrode starts to } \\
\text { slip out (max. transferable } \\
\text { force). }\end{array}$ & [30] \\
\hline Electrostatic adhesion & $\begin{array}{l}\text { Polyimide with nickel } \\
\text { electrodes }\end{array}$ & Bending (resistance) & $\begin{array}{l}\text { High-voltage current on Ni electrodes } \\
\text { stacked with polyimide layers and } \\
\text { then bending moment applied (3-point } \\
\text { bending) }\end{array}$ & $\begin{array}{l}\text { Analytical bending force } \\
\text { calculations for stacking } \\
\text { design. Difference from test } \\
\text { results originates from the } \\
\text { neglected interlaminar } \\
\text { friction at zero voltage. }\end{array}$ & $\begin{array}{l}\text { The applied voltage squeezed } \\
\text { layers together leading to } \\
\text { increased interlaminar friction } \\
\text { and bending stiffness. }\end{array}$ & [31] \\
\hline Ionic conducting polymer & $\begin{array}{l}\text { Electrochemically } \\
\text { deposited } \\
\text { polypyrrole-coated } \\
\text { nylon } 6 / 6 \\
\text { micro-ribbons }\end{array}$ & Bending/twisting & $\begin{array}{l}\text { Cyclic voltammetric measurements of } \\
\text { free-standing micro-ribbons }(-0.6 \mathrm{~V} \text { to } \\
\qquad+0.6 \mathrm{~V})\end{array}$ & - & $\begin{array}{l}\text { Significant twisting with a } \\
\text { response time of } \sim 5 \mathrm{~s}(0.6 \mathrm{~V}) \text { for } \\
\text { the single-side-coated ribbons. } \\
\text { (Temperature and } \mathrm{pH} \text { activity } \\
\text { tested as well) }\end{array}$ & [33] \\
\hline Ionic gel & $\begin{array}{l}\text { Bucky gel (tri-layer } \\
\text { gelatinous mixture of } \\
\text { electrolyte film, } \\
\text { carbon nanotubes and } \\
\text { ionic liquid) }\end{array}$ & Bending & $\begin{array}{l}\text { Electrical current }(2 \mathrm{~V}) \text { to actuator } \\
\text { while measuring blocking force }\end{array}$ & $\begin{array}{l}\text { Two-carrier model for } \\
\text { back-relaxation of } \\
\text { Bucky-gel }\end{array}$ & $\begin{array}{l}\text { Maximal blocking force of } 2 \\
\mathrm{mN} \text { with back relaxation after a } \\
\text { few seconds due to the } \\
\text { relocation of anions and cations }\end{array}$ & [35] \\
\hline Electro-responsive hydrogel & $\begin{array}{l}\text { Hydrogel with } \\
\text { aluminum hydroxide } \\
\text { nanoparticles }\end{array}$ & Bidirectional bending & $\begin{array}{l}\text { Dyed hydrogel strip placed between } \\
\text { two Pt electrodes in } \mathrm{Na}_{2} \mathrm{SO}_{4} \text { solution. } \\
\text { Bending due to applied electricity. }\end{array}$ & - & $\begin{array}{l}\text { Bidirectional bending, cyclic } \\
\text { actuation (10 times) and high } \\
\text { tensile strength of } 2 \text { MPa were } \\
\text { demonstrated }\end{array}$ & [37] \\
\hline Electro-origami/electro-ribbon & $\begin{array}{l}\text { Steel strips } \\
\text { insulated with PVC } \\
\text { tape }\end{array}$ & $\begin{array}{l}\text { Closing separate } \\
\text { strips }\end{array}$ & $\begin{array}{l}\text { Cyclic stimulation testing }(100,000 \\
\text { cycles) }\end{array}$ & $\begin{array}{l}\text { Analytical interfacial } \\
\text { (attraction) force } \\
\text { calculations }\end{array}$ & $\begin{array}{l}\text { Electro-ribbon actuator lifts } \\
\text { thousand-fold its weight and } \\
\text { contracts by more than } 99 \% \\
\text { with a specific energy similar } \\
\text { to the specific energy of human } \\
\text { muscle }\end{array}$ & [40] \\
\hline
\end{tabular}




\section{Shape Adaptation Actuated by Heat, Light, Pressure and Chemicals}

This section discusses shape-changing material concepts where actuation is realized either thermally, chemically or by applied light or pressure.

The simplest thermally actuated morphing materials exploit thermal expansion. Bimetals, for instance, consist of two different metals attached together. As the coefficients of thermal expansion for the two metals differ, they elongate at a different rate in response to applied heat leading to a bending moment and thus deformation of the structure. Pre-buckled bimetals can even be used as heat engines due to their thermo-mechanical instability (snap-through energy release) [41,42].

Shape memory alloys (SMAs) deform as a result of solid phase transitions. When cooled down, the so-called twinned martensite phase of the material can be deformed by loads. When heated, the material enters a cubic, symmetric austenite phase, regaining its original shape [43]. Kim et al. [6] developed a nickel titanium (NiTi) alloy coil spring actuator that can be used as an artificial muscle due to its high energy density contraction in response to applied heat. Shaw et al. [44] even demonstrated that NiTi honeycomb structures exhibit not only significant shape memory behavior but a high level of superelasticity as well, when loaded in-plane. Although most SMA research focus on NiTi alloys, there are other materials showing similar behavior, too. Ogawa et al. [45], for instance, introduced a magnesium alloy that has similar properties to conventional NiTi SMAs but for only two-thirds the weight.

Shape memory polymers (SMPs) are similar to SMAs in the sense that they are able to regain their original form in response to external stimuli (Figure 3). Although there are SMPs that are excited either electrically (Joule heating) [46] or by light [47], most of these polymers are actuated thermally. SMPs are cross-linked polymers with so-called transition segments between links. When heated above the transition temperature (either $\mathrm{T}_{\mathrm{g}}$ or $\mathrm{T}_{\mathrm{m}}$ depending on crystallinity), the transition segments display a drop in stiffness therefore the material becomes easily deformable, but the cross-linked structure hinders translations. Subsequent cooling fixes the deformed shape, and the original shape is regained through elastic recovery when the material is heated again. Some SMPs can elongate up to ten times their original lengths prior to failure [48], while others can have recoverable strains of $800 \%$ [49]. This makes these materials extremely useful where high deformations are needed (e.g., biomedicine), unlike SMAs, which have approximately $8 \%$ maximum strain [50]. The shape memory effect can also be exploited to produce artificial muscles with coiled geometries [51]. Despite the outstanding recoverable strain capacity, the applicability of SMPs is limited due to their low strength and recovery stress. To overcome this limitation, SMPs are often used as a matrix of composites. The most common reinforcements are fibers [52] and carbon nanotubes [53]. The latter is useful for Joule-heating, too.

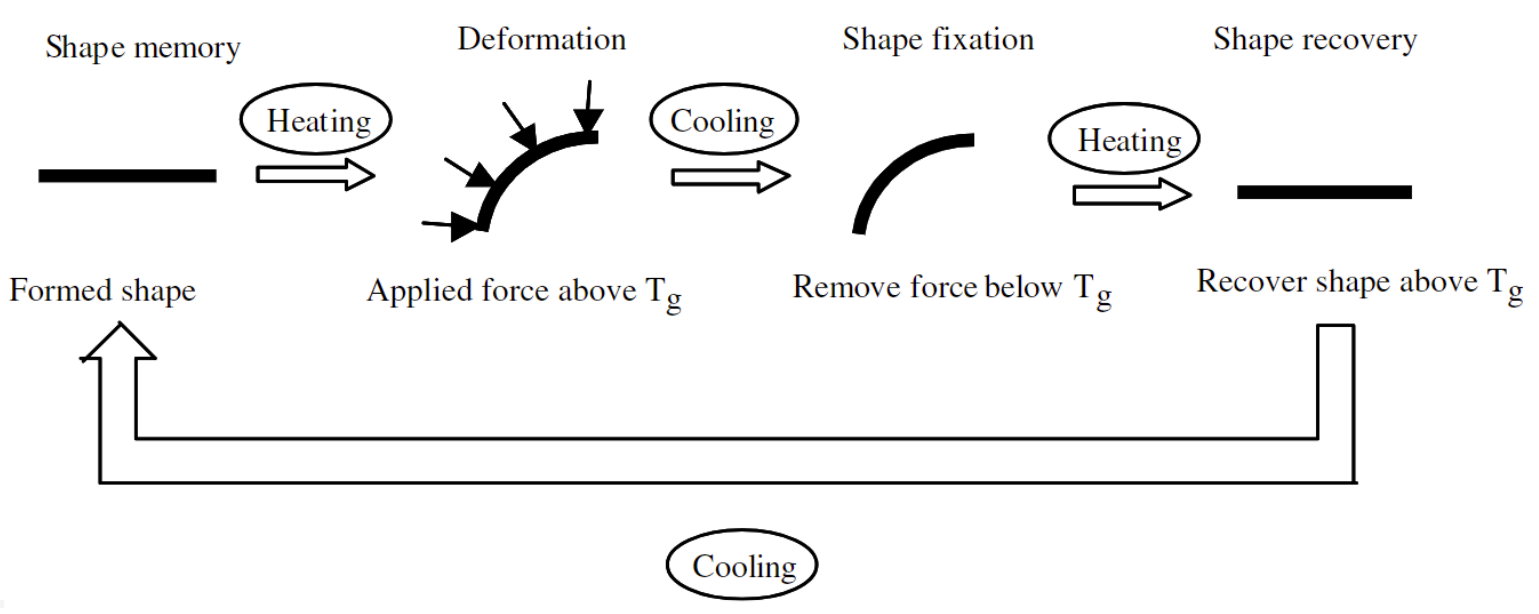

Figure 3. Schematic working principle of shape memory polymers [52]. 
Heat can trigger the deformation of so-called liquid crystal polymers, too. The deformation is a consequence of a crystalline to amorphous phase transition by the realignment of mesogens. During the initial programming of the material, mesogen alignment can be achieved in various ways (e.g., electric fields or mechanical loading), after which crosslinking the polymer finishes the process. Heat causes the mesogens to get disoriented, leading to often large deformations [54,55]. Yang et al. [56], for instance, demonstrated $300 \%$ to $400 \%$ reversible contractions of micron-sized liquid crystal elastomers.

Hygromorphic materials work by the principle of controlled water swelling, but the swelling of some of these systems greatly depends on the temperature. At a certain temperature, some hygromorphic materials change from a swollen hydrophilic phase to a shrunk hydrophobic one [57]. With a tri-layer structure, Na et al. [58] demonstrated large deformations of a flat sheet to applied heat. The deforming structure could reversibly form an origami bird (Figure 4), the response time being the limitation of the approach with a few minutes required for total folding.

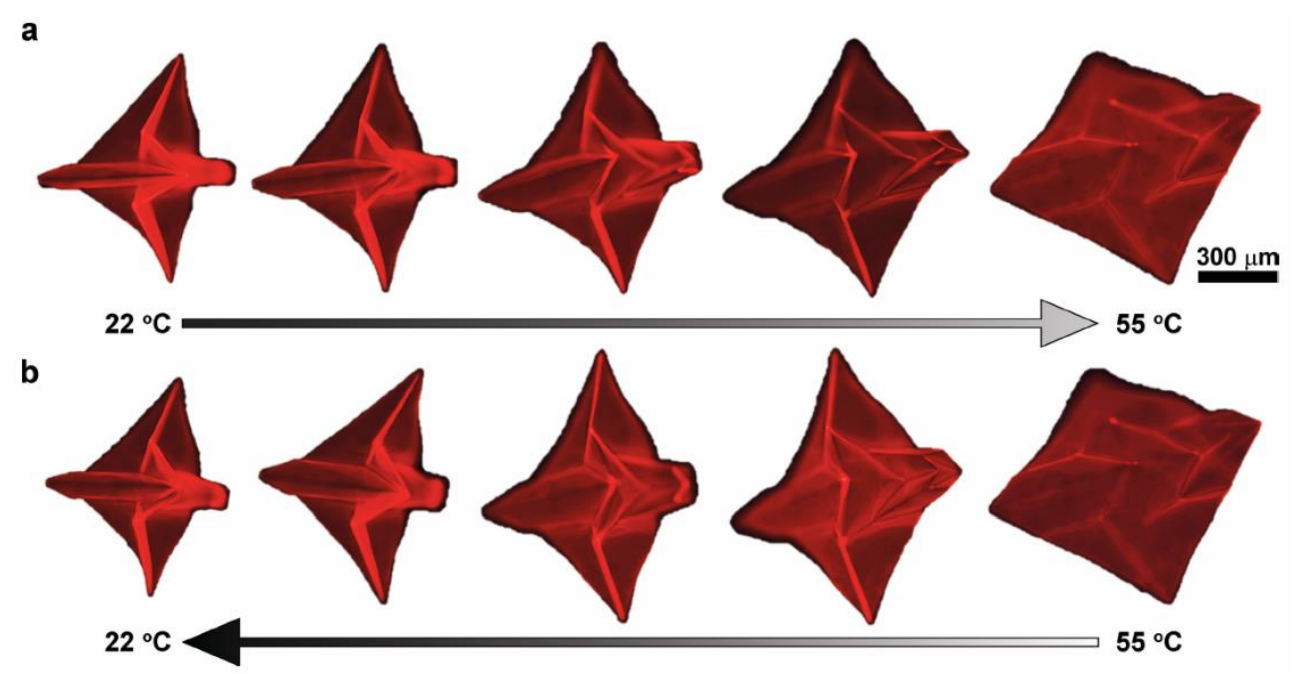

Figure 4. Thermally actuated origami folding: (a) cooling, deswelling and flattening, (b) heating, swelling and folding [58].

Although light-actuated shape changing materials might not be as extensively researched as electrically or thermally actuated systems, several different photoresponsive concepts exist due to their advantages, such as the good controllability and focusability of the actuating light. The precise, local stimuli can even allow for nanoscale shape adaptation responses. Irradiation usually leads to a reversible change in at least one property, such as the shape of the material [59]. Besides or instead of actuation by heat, some SMPs and liquid crystal polymers can be actuated by light, too. In most cases, photoactive SMPs contain photoreactive molecules to ensure photoresponse $[47,60]$, but a nanocoat layer on the surface of a simple thermally active SMP can also imbue it with photoactivity [61].

Photoresponsive liquid crystal polymers usually contain azobenzene fillers to operate. Most of these actuators are thin films showing bending deformations. This is due to the primarily superficial effect of the light that contracts the outer layer causing the film to bend. These actuators are relatively easy and inexpensive to manufacture, but their thermal instability and often long response times limited their applicability for a long time [62]. Recently, however, Zeng et al. [63] demonstrated a photoactive liquid crystal polymer with a response frequency of almost $2000 \mathrm{~Hz}$, overcoming one of the main disadvantages. Photoresponsive gels exist too, but they are often actuated through photothermal effects rather than purely by light. Wei and Yu [64] achieved photo-actuated contraction of 70\% of a thermally sensitive hydrogel with azobenzene. However, that change in volume took approximately 60 minutes, showing one of the main disadvantages of these materials once again.

Pressure is most commonly used for actuation in the conventional piston-cylinder setup. Depending on the pressurized medium, pressure actuated systems are usually categorized into two 
groups: pneumatic (compressible fluid) and hydraulic (practically uncompressible fluid). Although the microscaling of these systems is a challenge due to the required low-friction microseals, piston-cylinder microactuators do exist [65].

Numerous other pressure-actuated concepts have been proposed in the past decades. Most of them can be categorized into a group called elastic fluidic actuators (EFA). Besides EFAs, drag-based actuators also exist. These use flowing fluids and exploit their drag force. Due to their working mechanism, these actuators usually operate smoothly but produce only moderate actuation forces [66].

EFAs can be further divided into sub-categories such as membrane [67], balloon [68] and bellow [69] types and artificial muscles [70], of which the first two types are the most common. Membrane actuators are usually elastic sheets, which can be expanded by pressure. Membranes with corrugated surfaces are often used to grab objects [71]. One of the main limitations of membranes is the limited deformation they are capable of. Balloon actuators, on the other hand, are much more versatile in terms of achievable deformation and can produce non-conventional deformations, too.

Balloon-type actuators can bend, twist or extend/contract when pressurized, depending on the design of the actuator. Gorissen et al. [72] achieved large bending deflections of an elastic cylinder with a pressurizable eccentric inner void going along its length. The simple working principle is that the line of action of the applied force is offset from the neutral axis of the cylinder when the internal void is pressurized, leading to a bending moment and the bending of the whole structure. Ikeuchi et al. [68] achieved pressure-activated bending, too, but with a slightly different approach. They developed a micro-membrane with one flat side and the other side consisting of connected micro-chambers in length-section view. When internal hydraulic (water) pressure is increased, the chambers would expand leading to bending in the opposite direction. The concept was shown to be suitable for miniaturization, which is often a major concern in medical applications, for instance. It is also possible to achieve bending by connecting blocks with inflatable balloons. This way, segments can "bend" relative to each other when pressure is applied [7]. Moreover, based on very similar mechanisms to the ones just discussed, torsion [73,74] and extension or contraction [75] can be achieved, where the mode of deformation mainly depends on the design and position of the pressurizable chambers (Figure 5).

Shape changes can be actuated chemically, too. The simplest concepts build on controlled swelling and usually do not require any chemical reaction. These still count as chemical actuation, as the actuator is a chemical agent, usually water. As mentioned before, hygromorphic materials can change between a hydrophilic and a hydrophobic state with temperature, therefore, they are practically chemically actuated systems to some extent [57]. One of the most researched concepts builds on the biomimetics of the sea cucumber dermis. It is possible to manufacture a nanocomposite system that consists of percolating nanofibers with hydrogen bonds between them, making the structure stiff. However, when water is added, the structure loses the majority of its stiffness due to the competitive bonding effect where water-fiber bonds prove to be stronger than fiber-fiber bonds [76,77]. This way, water can significantly influence the stiffness and therefore the shape changing capability of the structure. The $\mathrm{pH}$ level of the surrounding medium can cause changes in dimension and shape, too, typically through the ionization of certain functional groups [78].

Table 2 lists some of the shape-changing concepts actuated by either heat, light, pressure or chemicals. 
a) Schematic of buckling actuator

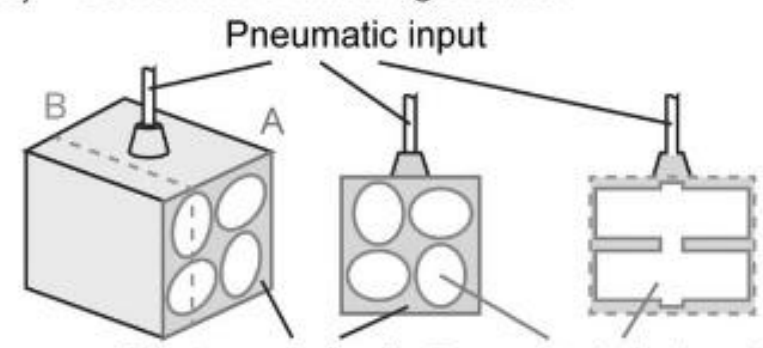

Elastomeric body Connected air chambers $3 \mathrm{D}$ view Front view (A) Cross-section (B)

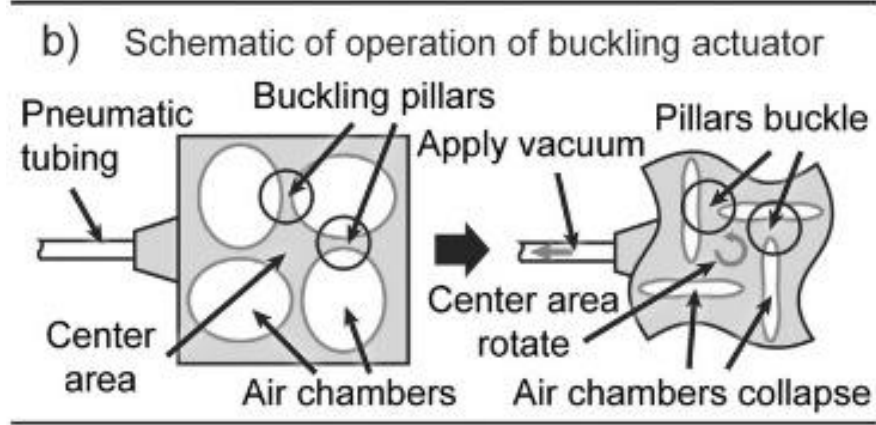

c) Pneumatic actuation

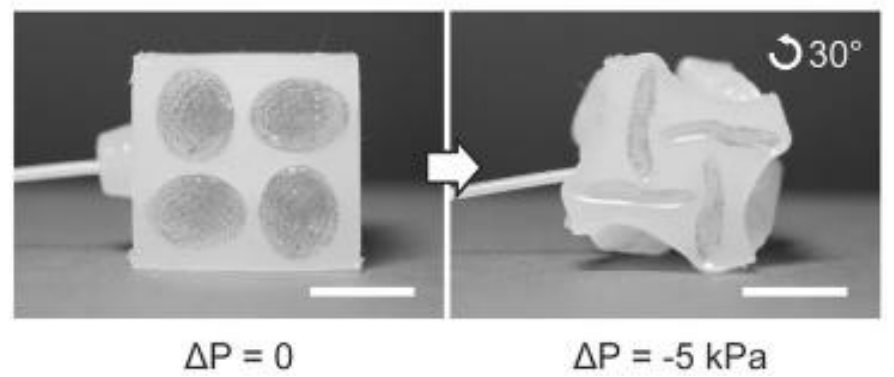

Figure 5. Schematics of a pneumatic buckling actuator. (a) actuator structure, (b) actuator operation, (c) pneumatic actuation [73]. 
Table 2. Heat-, light-, pressure- and chemically actuated non-conventional deformations.

\begin{tabular}{|c|c|c|c|c|c|c|}
\hline Working Principle & $\begin{array}{c}\text { Deforming } \\
\text { Material/Structure }\end{array}$ & Deformation Mode & Testing & Modeling & $\begin{array}{l}\text { Measurement Results, } \\
\text { Comments }\end{array}$ & Reference \\
\hline $\begin{array}{l}\text { Bimetal } \\
\text { (thermal) }\end{array}$ & $\begin{array}{l}\text { INVAR (low CTE) and } \\
\text { B72M (high CTE) alloy } \\
\text { curved bimetal strip }\end{array}$ & $\begin{array}{l}\text { Bending and } \\
\text { snap-through }\end{array}$ & $\begin{array}{l}\text { Power management circuit (energy } \\
\text { harvester, DC-to-DC converter, } \\
\text { storage). Measuring electric output } \\
\text { power. }\end{array}$ & $\begin{array}{l}\text { Circuit modelling and } \\
\text { analytical calculations for } \\
\text { output power }\end{array}$ & $\begin{array}{l}\text { More than } 13 \mu \mathrm{W} \text { output power } \\
\text { for a } 0.26 \mathrm{~g} \text { bimetal with } 3 \mathrm{~cm}^{2} \\
\text { surface when placed on } 60^{\circ} \mathrm{C} \\
\text { hot source }\end{array}$ & [42] \\
\hline $\begin{array}{l}\text { Shape memory alloy } \\
\text { (thermal) }\end{array}$ & NiTi coiled spring & $\begin{array}{l}\text { Contraction (spring } \\
\text { effect) }\end{array}$ & $\begin{array}{l}\text { Weight placed on free-hanging } \\
\text { spring (in martensite phase) and } \\
\text { then heat applied for contraction } \\
\text { (change to austenite phase). } \\
\text { Displacement measured. }\end{array}$ & $\begin{array}{l}\text { Effective displacement } \\
\text { calculations }\end{array}$ & $\begin{array}{l}500 \text { mm long coil with } 400 \mu \mathrm{m} \\
\text { diameter: more than } 1000 \mathrm{~J} / \mathrm{kg} \\
\text { energy density and } 50 \% \\
\text { contraction }\end{array}$ & [6] \\
\hline $\begin{array}{l}\text { Shape memory } \\
\text { polymer (thermal) }\end{array}$ & $\begin{array}{l}\text { Multiblock copolymer } \\
\text { (switching and hard } \\
\text { segments) }\end{array}$ & $\begin{array}{l}\text { Regaining original } \\
\text { shape }\end{array}$ & $\begin{array}{l}\text { Cyclic thermomechanical tests } \\
\text { (straining, fixing, applying heat to } \\
\text { recover) }\end{array}$ & - & $\begin{array}{l}\text { Strain fixing capability up to } \\
99.5 \% \text { and strain recovery rate } \\
\text { approaching } 100 \% \text { depending on } \\
\text { the number of cycles }(\sim 80 \% \text { in } \\
\text { the first cycle) }\end{array}$ & [48] \\
\hline $\begin{array}{l}\text { Shape memory } \\
\text { polymer (thermal) }\end{array}$ & Multiblock copolymer & $\begin{array}{l}\text { Regaining original } \\
\text { shape }\end{array}$ & $\begin{array}{l}\text { Thermomechanical and sol-gel tests } \\
\text { (spectrometry and NMR for } \\
\text { chemical structure) }\end{array}$ & - & $807 \%$ recoverable strain & [49] \\
\hline $\begin{array}{l}\text { Shape memory } \\
\text { polymer composite } \\
\text { (thermal) }\end{array}$ & $\begin{array}{l}\text { Multi-walled carbon } \\
\text { nanotube-filled } \\
\text { polyurethane SMP }\end{array}$ & $\begin{array}{l}\text { Regaining original } \\
\text { shape }\end{array}$ & $\begin{array}{l}\text { Voltage applied to samples and } \\
\text { shape change monitored } \\
\text { (FT-IR for reactive group } \\
\text { investigation and DSC for transition } \\
\text { temperature) }\end{array}$ & $\begin{array}{l}\text { Calculation of the efficiency } \\
\text { of energy conversion }\end{array}$ & $\begin{array}{l}\text { Increased stress and modulus at } \\
100 \% \text { elongation but decreased } \\
\text { failure strain compared to the } \\
\text { unfilled SMP. } \sim 10 \% \text { efficiency of } \\
\text { energy conversion }\end{array}$ & [53] \\
\hline $\begin{array}{l}\text { Liquid crystal } \\
\text { elastomer - LCE } \\
\text { (thermal) }\end{array}$ & Micron-sized LCE pillars & Contraction & $\begin{array}{l}\text { Heating individual LCE pillars and } \\
\text { investigating their contraction under } \\
\text { a microscope }\end{array}$ & - & $\begin{array}{l}300 \% \text { to } 400 \% \text { recoverable } \\
\text { contraction }\end{array}$ & [56] \\
\hline $\begin{array}{l}\text { Hygromorphic } \\
\text { material (thermal) }\end{array}$ & $\begin{array}{l}\text { Patterned trilayer film } \\
\text { (PpMS/PNIPAM/PpMS) }\end{array}$ & $\begin{array}{l}\text { Origami (localized } \\
\text { swelling) }\end{array}$ & $\begin{array}{l}\text { Origami structure submerged into } \\
\text { heat-transfer liquid and heated from } \\
22{ }^{\circ} \mathrm{C} \text { to } 55^{\circ} \mathrm{C} \text { (and cooled back). } \\
\text { Shape change investigated in } \\
\text { thermal equilibriums }\end{array}$ & Folding angle calculations & $\begin{array}{l}\text { Reversible complex-shaped } \\
\text { self-folding origami }\end{array}$ & [58] \\
\hline $\begin{array}{l}\text { Shape memory } \\
\text { polymer (light) }\end{array}$ & $\begin{array}{l}\text { Polydopamine } \\
\text { nanocoated SMP }\end{array}$ & $\begin{array}{c}\text { Regaining original } \\
\text { shape }\end{array}$ & $\begin{array}{l}\text { Photo-responsiveness is measured } \\
\text { with a dynamic mechanical analyzer } \\
\text { (DMA) while keeping the strain fixed }\end{array}$ & $\begin{array}{c}\text { Finite element modelling } \\
\text { (mechanical) to simulate } \\
\text { the nanocoat } \\
\text { pattern-bending behavior } \\
\text { relationship }\end{array}$ & $\begin{array}{l}\text { Efficient photoactuation } \\
\text { performance without worsening } \\
\text { the original functionality or } \\
\text { mechanical properties of the } \\
\text { heat-actuated SMP }\end{array}$ & [61] \\
\hline
\end{tabular}


Table 2. Cont

\begin{tabular}{|c|c|c|c|c|c|c|}
\hline Working Principle & $\begin{array}{c}\text { Deforming } \\
\text { Material/Structure }\end{array}$ & Deformation Mode & Testing & Modeling & $\begin{array}{l}\text { Measurement Results, } \\
\text { Comments }\end{array}$ & Reference \\
\hline $\begin{array}{l}\text { Liquid crystal } \\
\text { elastomer (light) }\end{array}$ & $\begin{array}{l}\text { LCE sheet with } \\
\text { azobenzene }\end{array}$ & Bending & $\begin{array}{l}\text { Dual circuit test setup: bending LCE } \\
\text { sheet closes circuit and illuminates a } \\
\text { LED lamp. One side bending to UV, } \\
\text { opposite side bending to humidity. }\end{array}$ & - & $\begin{array}{l}\text { Successful demonstration of a } \\
\text { touchless electronic device } \\
\text { actuated by either humidity or } \\
\text { UV light resulting in opposite } \\
\text { bending responses. }\end{array}$ & [79] \\
\hline $\begin{array}{c}\text { Pneumatic } \\
\text { (pressure) }\end{array}$ & $\begin{array}{l}\text { Wing structure with } \\
\text { aluminum rib sections } \\
\text { covered with latex sheet }\end{array}$ & camber & $\begin{array}{l}\text { Wind tunnel-load cell balance test to } \\
\text { measure lift and drag }\end{array}$ & - & Up to $10 \%$ change in camber & [80] \\
\hline $\begin{array}{l}\text { EFA-balloon } \\
\text { (pressure) }\end{array}$ & $\begin{array}{c}\text { Elastic } \\
\text { polydimethylsiloxane } \\
\text { (PDMS) cylinder with } \\
\text { eccentric, pressurizable } \\
\text { internal void }\end{array}$ & bending & $\begin{array}{l}\text { Statically pressurized cylinders with } \\
\text { different void eccentricities and radii }\end{array}$ & $\begin{array}{c}\text { Analytical Euler-Bernoulli } \\
\text { calculations (not accurate at } \\
\text { large deflections) and finite } \\
\text { element analysis for } \\
\text { cross-sectional } \\
\text { deformations and stresses }\end{array}$ & $\begin{array}{l}\text { Example result: } 0.14 \mathrm{~mm}^{-1} \\
\text { curvature at a pressure of } 0.1 \\
\mathrm{MPa}(10 \mathrm{~mm} \text { length, } 0.5 \mathrm{~mm} \\
\text { diameter, } 0.09 \mathrm{~mm} \text { eccentricity } \\
\text { and } 0.35 \mathrm{~mm} \text { inner void radius })\end{array}$ & [72] \\
\hline $\begin{array}{l}\text { Hydraulic balloon } \\
\quad \text { (pressure) }\end{array}$ & $\begin{array}{l}\text { Elastic polymer with flat } \\
\text { bottom and folded } \\
\text { microchambers on top } \\
\text { (longitudinal section) }\end{array}$ & bending & $\begin{array}{l}\text { Pressurizing the water in the } \\
\text { membrane with a syringe and } \\
\text { measuring bending deformation }\end{array}$ & - & $\begin{array}{l}\text { Up to } 180^{\circ} \text { bending deformation } \\
\text { of micro-scale actuators }\end{array}$ & [68] \\
\hline $\begin{array}{l}\text { Pneumatic balloon } \\
\text { (pressure) }\end{array}$ & $\begin{array}{l}\text { "Microhand fingers" (4 } \\
\text { mm long) consisting of } \\
\text { silicone blocks connected } \\
\text { by inflatable balloons }\end{array}$ & bending & $\begin{array}{l}\text { Pressurizing balloons with } \\
\text { compressed air }\end{array}$ & - & $\begin{array}{l}\text { Full closure of microhand fingers } \\
\text { at } 240 \mathrm{kPa} \text { pressure }\end{array}$ & [7] \\
\hline Pneumatic (pressure) & $\begin{array}{l}\text { PDMS sheet with } \\
\text { patterned pressurizable } \\
\text { voids on two levels }\end{array}$ & torsion & $\begin{array}{l}\text { Pressurizing two sets of voids (left } \\
\text { and right sides of the actuator) on } \\
\text { the opposite sides of the neutral axis. } \\
\text { Opposing bending moments lead to } \\
\text { twisting. Torsional angle is } \\
\text { measured at different pressures. }\end{array}$ & $\begin{array}{l}\text { Analytical torsion angle } \\
\text { calculations }\end{array}$ & $\begin{array}{l}6.5^{\circ} \text { torsion for every } \mathrm{mm} \text { along } \\
\text { the length of the actuator }(7 \mathrm{~mm} \\
\text { wide, } 0.65 \mathrm{~mm} \text { thick) at } 178 \mathrm{kPa}\end{array}$ & [74] \\
\hline Chemical agent & $\begin{array}{l}\text { Poly(vinyl-acetate) } \\
\text { (PVAc) with percolating } \\
\text { cellulose nanofiber } \\
\text { system }\end{array}$ & (change in stiffness) & $\begin{array}{l}\text { Pouring water (as the chemical agent } \\
\text { for competitive hydrogen bonding) } \\
\text { to the PVAc with cellulose fibers and } \\
\text { measuring modulus }\end{array}$ & - & $\begin{array}{l}\text { A stiffness change of } 3 \text { orders of } \\
\text { magnitude (from } 5 \mathrm{GPa} \text { to } 5 \mathrm{MPa} \text { ) } \\
\text { due to dominant water-cellulose } \\
\text { hydrogen bonding compared to } \\
\text { cellulose-cellulose hydrogen } \\
\text { bonding }\end{array}$ & [76] \\
\hline
\end{tabular}




\section{Mechanically actuated shape adaptation}

Non-conventional shape changes can be actuated by mechanical loads, too. A typical limitation of these systems is that the deformations are usually difficult to control independently of the working conditions, especially in the case of structural parts that are inevitably under inconstant mechanical loads during operation. On the other hand, this "passive" actuation approach can be extremely advantageous when the operational mechanical loads are predictable and the optimal shapes to the various loading scenarios are known. For instance, the optimal angle of attack of turbine blades changes with wind speeds and a blade structure that would twist the right amount in response to increasing aerodynamic (bending) loads can significantly increase energy efficiency [81].

The mechanical behavior of structures greatly depends on their internal architecture. Mechanism-based shape-changing concepts often achieve controlled deformations by introducing changes to the internal architecture, leading to altered mechanical characteristics of the whole structure. Ajaj et al. [82,83] developed a wing-box capable of torsional stiffness adjustments with simple internal mechanisms. They tuned torsional stiffness by translating the span-wise spar webs closer to or further from the shear center of the cross-section of the wing-box. Greater distances from the shear center led to increased resistance to torsion, and the authors even identified optimal spar positions for three different flight scenarios by carrying out an optimization study. Runge et al. [84,85] proposed a different method to achieve controlled twisting by modifying the position of the shear center of an airfoil. They used clutch-like mechanisms to control the relative movement of internal discontinuous walls in a box section. When they released the clutch, the two halves of the discontinuous walls slid on each other, generating significantly less resistance to twisting than when the walls were fixed by the clutch. This way, they were able to control the twist angle of the wing section. This method, however, was still not absolutely "passive" as it needed external energy for actuation.

Other mechanically actuated shape-changing concepts utilize the bi- or multistability of materials or structures. These systems have at least two equilibrium states (and shapes) (Figure 6). Often there are large displacements between the distinct equilibriums, and the actuation energy needed for the snap-through between these states is relatively low. A limitation of these systems is the stepwise deformation - a threshold load activates the "mechanical switch" and results in a big jump in deflection, practically instantly. Most often, bistability is achieved with composites that have asymmetric layups. Because of the asymmetry, the thermal stresses do not cancel each other out in the out-of-plane direction when cooled down from the manufacturing temperature. This leads to warping and bistable behavior in some cases. Another similar approach does not build on asymmetry but on prestressed laminae in a symmetric composite layup. Prestressing leads to stress fields similar to those in asymmetric composites. The main advantage of the prestressing approach is the higher achievable snap-through force [86-88].
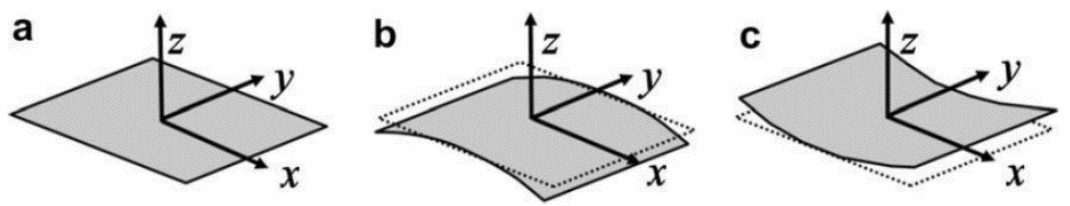

Figure 6. Bistable laminate (a) reference flat plate, (b) and (c) stable geometries [89].

Daynes et al. [90] developed an aeroelastic rotor blade with a bistable trailing edge. They used several internal laminates in the flap, where some laminae of each laminate were prestressed before and during the curing cycle. The mechanical behavior of the bistable flap was set by the properties and placement of the internal bistable laminates and a $10^{\circ}$ snap-through deflection was achieved. The magnitude of the deflection and the snap-through load can be tuned by the layup, material properties, number and placement of the constituting laminates, as well as by the magnitude of the 
prestressing, making the aerodynamic characteristics of the bistable structure tunable. Furthermore, with the right geometrical design, it is possible to achieve tristability with only bistable laminates [91].

One of the most promising mechanically actuated shape-changing concepts builds on the mechanical coupling between loads and deformations of different modes (e.g., twisting in response to bending loads). Composites with special layups can demonstrate such mechanical coupling behavior. Historically, fiber-reinforced composites are mainly used for their outstanding specific mechanical properties, but mechanical coupling can give them the multifunctionality they need to further spread as advanced structural materials.

In the case of composites, mechanical couplings are most often visualized as a set of coupling parameters in a $6 \times 6$ (so-called ABD) matrix, which establishes the relationship between six types of loads and six types of deformation (extension, transverse extension, in-plane shear, bending, transverse bending and twisting). This model is called the Classical Laminate Theory (CLT), and it is the simplest analytical model to characterize the mechanical behavior of composite laminates. The CLT builds on some assumptions (or simplifications), such as assuming plane stress state, linear elasticity and perfect interlaminar bonding, but these simplifications do not lead to major inaccuracies for thin laminates with small deformations. On the other hand, the low computational weight of the model and the fact that it quantifies each constituent of the coupling behavior with a single number for a given laminate allow for relatively simple design, evaluation and optimization. York [92] categorized and characterized composite laminates based on their coupling behavior. He found that the $3 \times 3$ extensional (A), bending (D) and extensional-bending (B) matrices can be populated (with non-zero terms) in only a few different ways, which depend on the layup of the composite. Moreover, any of the aforementioned six loads can lead to any of the six types of deformation. The only question is the magnitude of the coupling effect and how the layup needs to be designed to achieve the selected kind of coupling. York also published papers individually dedicated to extension-shear [93], extension-twist [94] and bend-twist [95] coupled composites with design recommendations for each case.

Extension-shear coupling is amongst the least researched coupling modes, although it has been demonstrated that it can produce significant and useful bend-twist coupling by strategically placing the laminates on a wing-box [93]. Li et al. [96] even demonstrated that hygro-thermal shearing distortion of extension-shear coupled laminates can be reduced, which might lead to an increased research interest in these laminates in the future.

Extension-twist coupling can be exploited in helicopter rotor blades, for instance. At higher rotational speeds, extensive loading becomes greater and leads to increasing twisting deformation of the blades. This way the blades can produce more lift, making the vehicle more efficient $[94,97]$. Similarly to extension-shear laminates, extension-twist laminates can be designed to be hygro-thermally stable, too [98].

Bend-twist coupled composites are most often used as the primary materials of marine $[8,99,100]$ or wind turbine blades [101]. Mortley et al. [8] demonstrated that a marine turbine with bend-twist composite blades can work significantly more efficiently under most circumstances compared to a turbine with rigid blades (Figure 7). Coupled composites can not only make structures more efficient, but can push their applicability limits further, too. Shakya et al. [101], investigated the effect of bend-twist composites as the skin material of wind turbine blades. They found that they were able to increase the critical flutter speed of a turbine by $100 \%$. 


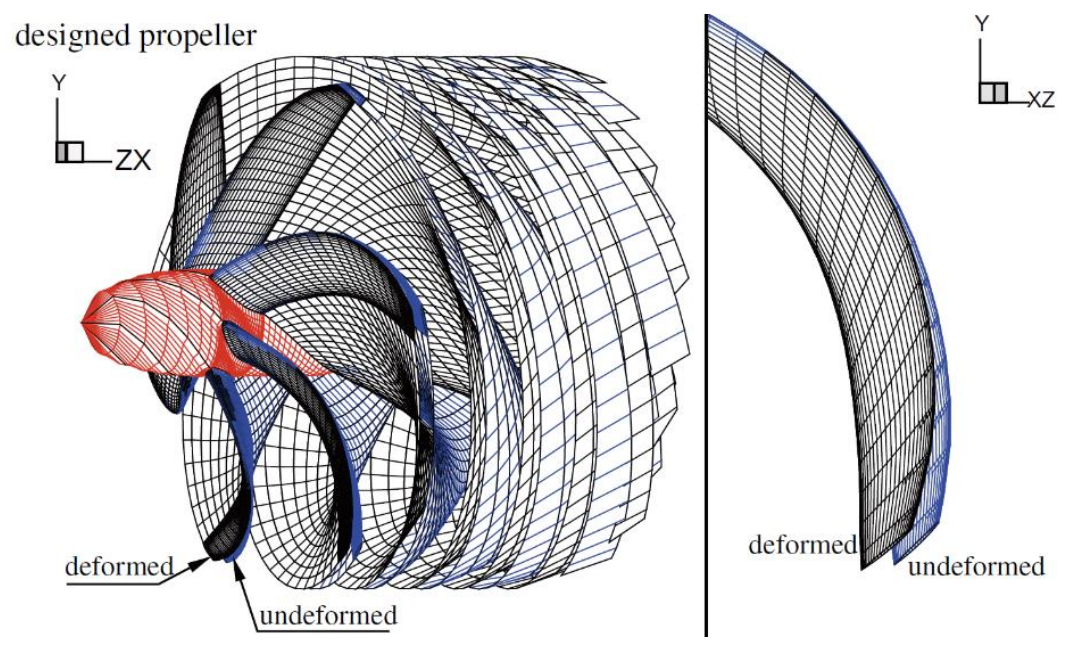

Figure 7. Undeformed and deformed geometry of a marine turbine with bend-twist coupled composite blades for improved efficiency [8].

Using composites may not be the only way to achieve advanced mechanically actuated shape changes, but their outstanding specific mechanical properties and great tailorability of their mechanical behavior make these materials one of the most interesting and most promising candidates when it comes to developing more and more efficient structures, which is without a doubt the tendency in today's industry.

Table 3 contains information about some mechanically actuated shape-changing concepts. 
Table 3. Mechanically actuated non-conventional deformations.

\begin{tabular}{|c|c|c|c|c|c|c|}
\hline Working Principle & $\begin{array}{c}\text { Deforming } \\
\text { Material/Structure }\end{array}$ & Deformation Mode & Testing & Modeling & $\begin{array}{l}\text { Measurement Results, } \\
\text { Comments }\end{array}$ & Reference \\
\hline $\begin{array}{l}\text { Internal mechanism } \\
\quad \text { (translation) }\end{array}$ & $\begin{array}{c}\text { Span-wise spars } \\
\text { translating closer to or } \\
\text { further from each other in } \\
\text { wing box }\end{array}$ & $\begin{array}{l}\text { (Resistance to) } \\
\text { twisting }\end{array}$ & - & $\begin{array}{l}\text { Quasi-static aeroelastic } \\
\text { suite developed in } \\
\text { MATLAB to model the } \\
\text { adaptive torsion wing } \\
\text { (plus FE model) }\end{array}$ & & [82] \\
\hline $\begin{array}{l}\text { Internal mechanism } \\
\text { (clutch) }\end{array}$ & $\begin{array}{l}\text { Span-wise discontinuous } \\
\text { internal walls fixed or } \\
\text { released by a simple } \\
\text { clutch system }\end{array}$ & $\begin{array}{l}\text { (Resistance to) } \\
\text { twisting }\end{array}$ & $\begin{array}{l}\text { Measuring rotation as a } \\
\text { function of applied force } \\
\text { and wall displacements } \\
\text { (fixed with clutches) }\end{array}$ & $\begin{array}{c}\text { Analytical torsional } \\
\text { stiffness calculations } \\
\text { (Euler-Bernoulli, } \\
\text { Saint-Venant, etc.) }\end{array}$ & $\begin{array}{l}\text { Linear correlation between wall } \\
\text { displacement and torsion, and } \\
\text { significantly modifiable shear } \\
\text { center for further torsion control }\end{array}$ & [85] \\
\hline Bistability & $\begin{array}{l}\text { Symmetric (prestressed) } \\
\text { carbon fiber reinforced } \\
\text { composite laminate }\end{array}$ & $\begin{array}{l}\text { Snap-through } \\
\text { between bistable } \\
\text { states (bending and } \\
\text { twisting) }\end{array}$ & $\begin{array}{l}\text { Prestressing certain } \\
\text { laminae prior to curing. } \\
\text { Measuring snap-through } \\
\text { loads after curing. }\end{array}$ & $\begin{array}{l}\text { Analytical and finite } \\
\text { element modelling of } \\
\text { prestressed laminate } \\
\text { bistability }\end{array}$ & $\begin{array}{c}\text { Up to } 72 \% \text { increase in } \\
\text { snap-through loads compared to } \\
\text { asymmetric (and } \\
\text { non-prestressed) bistable } \\
\text { laminates for a 4-ply composite. } \\
\text { The reduced hygrothermal } \\
\text { variability of prestressed } \\
\text { symmetric composites compared } \\
\text { to asymmetric ones is another } \\
\text { advantage. }\end{array}$ & [87] \\
\hline Bistability & $\begin{array}{l}\text { Rotor blade flap } \\
\text { consisting of symmetric } \\
\text { prestressed carbon fiber } \\
\text { reinforced composite } \\
\text { laminates }\end{array}$ & $\begin{array}{l}\text { Snap-through } \\
\text { between bistable } \\
\text { states (bending } \\
\text { deflection) }\end{array}$ & $\begin{array}{l}\text { Bending moment applied } \\
\text { to the laminates on a } \\
\text { tensile machine while } \\
\text { measuring force and } \\
\text { deflection. }\end{array}$ & $\begin{array}{l}\text { Analytical calculations } \\
\text { for deflection and work } \\
\text { (plus numerical } \\
\text { simulations) }\end{array}$ & $\begin{array}{l}10^{\circ} \text { snap-through deflection of } \\
\text { the bistable flap. The } \\
\text { snap-through load and deflection } \\
\text { are tunable by the number, layup, } \\
\text { material properties and } \\
\text { placement of the laminates and } \\
\text { by the applied prestressing. }\end{array}$ & [90] \\
\hline Coupled composite & $\begin{array}{c}\text { Carbon-epoxy composite } \\
\text { box beam }\end{array}$ & Twisting to extension & $\begin{array}{l}\text { Beam tests for validating } \\
\text { the finite element } \\
\text { analyses }\end{array}$ & $\begin{array}{l}\text { Dynamic aeroelastic finite } \\
\text { element analysis of the } \\
\text { "self-twisting" rotor blade }\end{array}$ & $\begin{array}{c}20 \% \text { maximal improvement of } \\
\text { lift-to-drag ratio compared to } \\
\text { uncoupled blades }\end{array}$ & [97] \\
\hline Coupled composite & $\begin{array}{l}\text { Carbon-epoxy composite } \\
\text { marine propeller }\end{array}$ & Twisting to bending & $\begin{array}{l}\text { Cavitation tank tests of a } \\
\text { propeller with a } 200 \mathrm{~mm} \\
\text { diameter rotated at } 7-20 \\
\text { rps ( } 3.55 \mathrm{~m} / \mathrm{s} \text { axial fluid } \\
\text { speed). Deformations } \\
\text { observed, thrust and } \\
\text { torque measured. }\end{array}$ & $\begin{array}{c}\text { Genetic algorithm-based } \\
\text { layup sequence } \\
\text { optimization and } \\
\text { numerical simulation of } \\
\text { the bend-twist behavior }\end{array}$ & $\begin{array}{l}\text { Propeller with optimized layup } \\
\text { passively changes its pitch angle } \\
\text { to changing ship speeds, leading } \\
\text { to improved torque curve and } \\
\text { efficiency. Numerical results } \\
\text { were difficult to compare to } \\
\text { experimental results because of } \\
\text { small deflections and vibrations. }\end{array}$ & [99] \\
\hline
\end{tabular}


Table 3. Cont

\begin{tabular}{|c|c|c|c|c|c|c|}
\hline Working Principle & $\begin{array}{c}\text { Deforming } \\
\text { Material/Structure }\end{array}$ & Deformation Mode & Testing & Modeling & $\begin{array}{l}\text { Measurement Results, } \\
\text { Comments }\end{array}$ & Reference \\
\hline Coupled composite & $\begin{array}{l}\text { Carbon-epoxy composite } \\
\text { marine propeller }\end{array}$ & Twisting to bending & - & $\begin{array}{l}\text { Numerical simulations } \\
\text { for pitch angle, working } \\
\text { efficiency, thrust and } \\
\text { power comparing the } \\
\text { bend-twist propeller with } \\
\text { a rigid one }\end{array}$ & $\begin{array}{l}\text { Bend-twist coupled propeller } \\
\text { works significantly more } \\
\text { efficiently compared to its rigid } \\
\text { counterpart in most cases. }\end{array}$ & [8] \\
\hline Coupled composite & $\begin{array}{l}\text { Fiber reinforced } \\
\text { composite wind-turbine } \\
\text { blade with asymmetric } \\
\text { skin layup }\end{array}$ & Twisting to bending & - & $\begin{array}{l}\text { Aeroelastic (structural } \\
\text { and aerodynamic) } \\
\text { modelling of the } \\
\text { mechanical behavior of } \\
\text { the composite blade }\end{array}$ & $\begin{array}{l}\text { Critical flutter speed of the blade } \\
\text { increased by } 100 \% \text {. This was } \\
\text { achieved by using bend-twist } \\
\text { coupled composites in the skin } \\
\text { instead of regular (symmetric) } \\
\text { layup. }\end{array}$ & [101] \\
\hline
\end{tabular}




\section{Applications}

So far, we have discussed a variety of different literary approaches to achieve non-conventional deformations. In this section, we present some actual applications of morphing structures and materials to show their industrial value.

More advanced Ford Mustang models use an active damping (suspension) system instead of a traditional one. The non-conventional deformation occurs on the microscale, where magnetic particles align themselves in lines when exposed to a magnetic field. This increases the apparent viscosity of the fluid, leading to increased stiffness of the damper. The change in viscosity happens in a few hundredths of a second and is reversible just as quickly. This way the car can adjust the stiffness of its suspension according to different driving situations (e.g., cornering), which results in a smoother and more efficient ride [102].

NextGen Aeronautics developed an aircraft capable of significant in-plane wing morphing to adapt to different flight scenarios. Multiple linear actuators modify the shape of the flexible elastomeric wing skin to achieve the complex deformations, and wind tunnel and even flight tests proved the functionality and positive aerodynamic effect of the system [103].

Thermally actuated deployable structures, such as SMP based systems, are great alternatives to conventional, heavier solutions for space applications. NASA, for instance, developed a 35-meter diameter radar to monitor weather anomalies (e.g., hurricanes) from space, but deploying such a huge structure requires novel solutions, for instance combining shape memory and inflatable structures to deploy the space radar [104].

In 2018, the Fraunhofer Institute for Wind Energy Systems (IWES) started the testing of bend-twist coupled composite wind turbine blades. The 20-meter long smart rotor blades are designed to adapt to the changing environmental conditions (i.e., wind speed and direction). This example shows that the concept is already at the level of industrial application [105].

In 2019, MIT and NASA engineers developed a wing assembly capable of passive shape changes in response to changing flight conditions (i.e., mechanical loads). The researchers emphasized that the structure shows shape changes similar to what was already possible previously, but now morphing is passive. This means a smart structure that operates more efficiently under a variety of conditions than its conventional counterparts. The wing is an assembly of a large number of components of different stiffness forming a lightweight lattice framework covered by a polymeric skin. Due to the clever design of the structure, it behaves as a metamaterial on the structural level. It is both rubbery and stiff with extremely light weight and shape adaptation capabilities (Figure 8) [106].

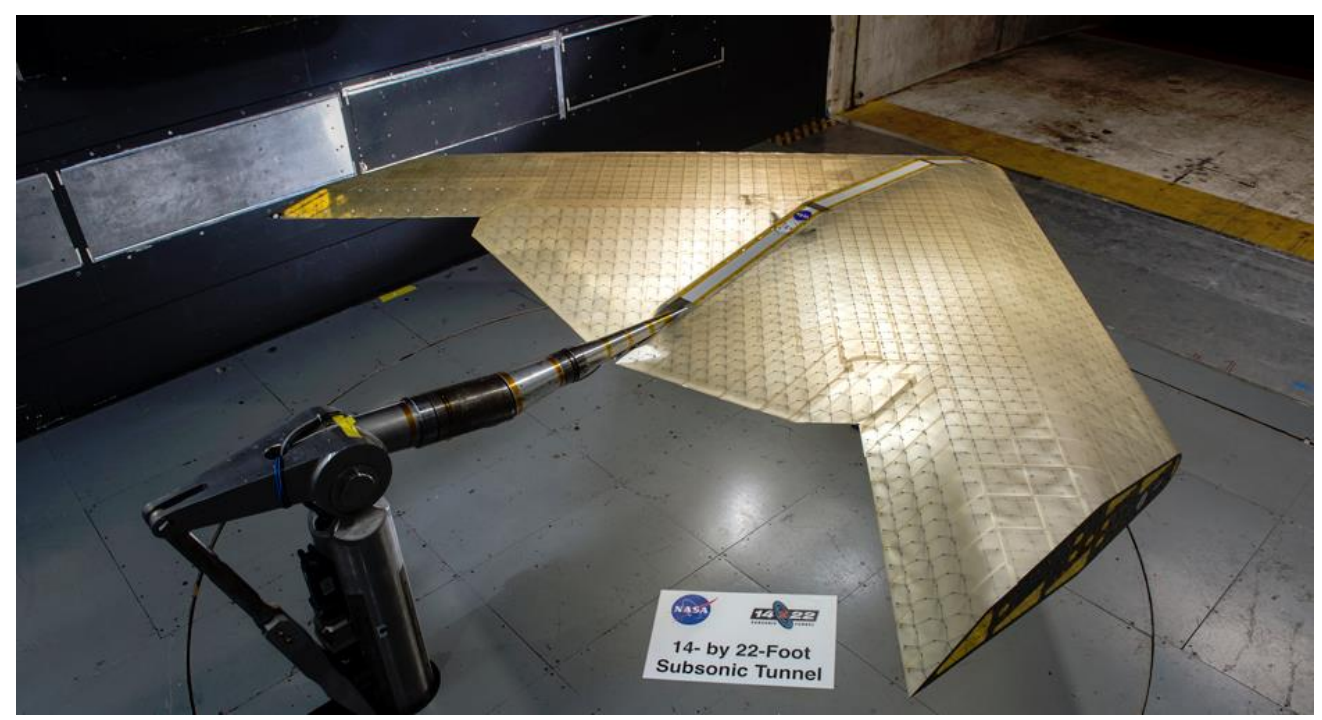

Figure 8. Passively morphing aircraft capable of shape adaptation to different flight conditions [106]. 
Although numerous other examples could be presented here for the industrial application of morphing materials, the selected concepts sufficiently demonstrate that materials and structures with non-conventional shape changes offer advanced solutions even at the highest levels of engineering (e.g., aerospace). Also, it is important to identify the applicability of certain morphing concepts regarding the scale of the desired shape change. Usually, piezo-electric actuation is more suited for the micro applications, while motorized concepts can be used on the larger scales, for instance. Taking other considerations into account (e.g., static or dynamic actuation, actuation force, etc.) too, the optimal actuation concept is always dependent on the application scenario.

\section{Summary and Outlook}

Non-conventional shape changes can be actuated in various ways (by electricity, heat, pressure, etc.), and numerous different concepts exist for each kind of actuation (Figure 9).

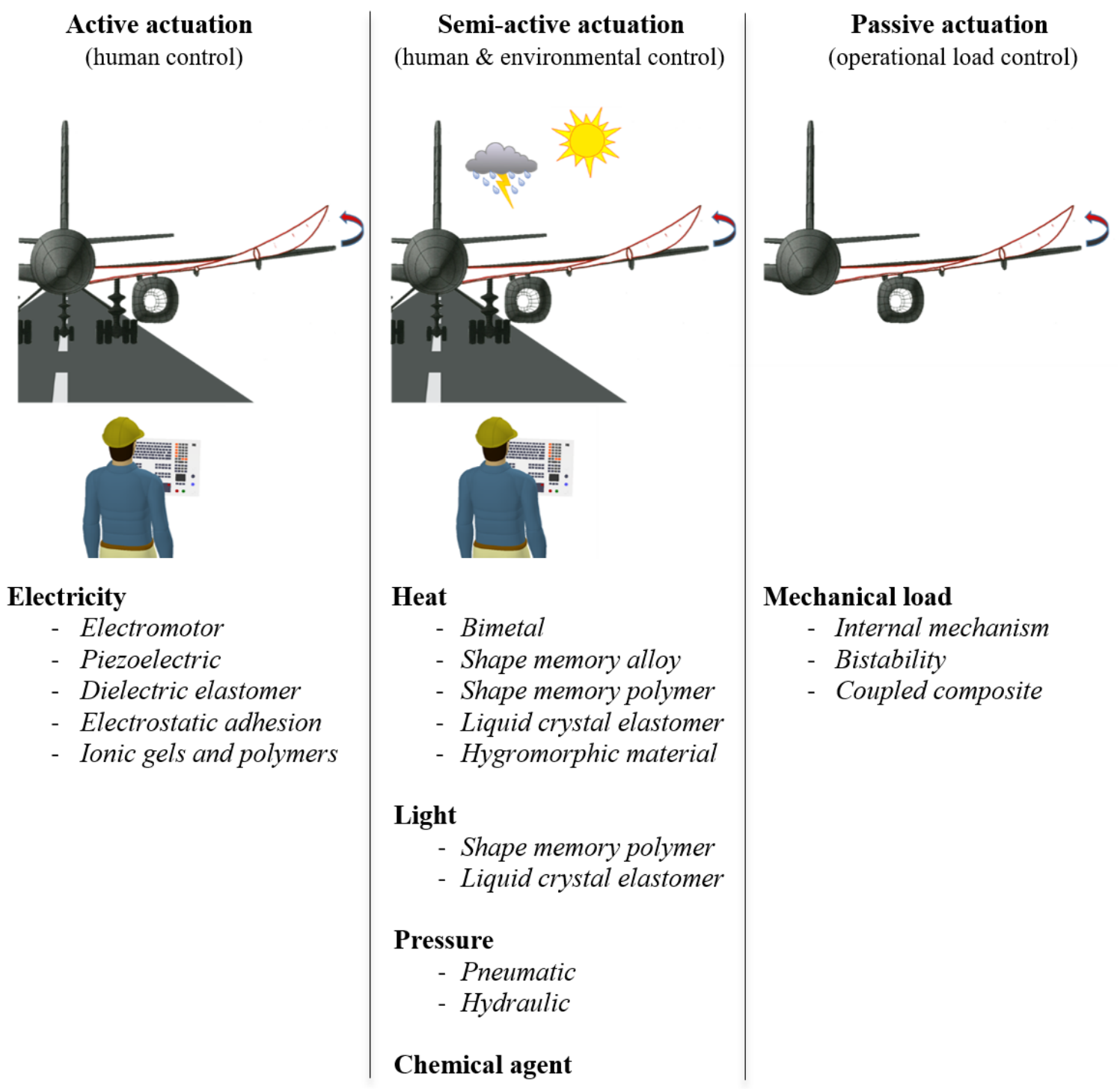

Figure 9. Schematic abstract of approaches to achieve non-conventional shape changes with.

Electromotors provide good controllability when deforming structures, therefore they are widely used in the industry, however the weight they add to any system is a significant disadvantage. Weight reduction and efficiency improvement are some of the main driving forces of research aiming to develop materials that demonstrate shape changes other than conventional deformation (e.g., 
extension in response to tensile force or bending in response to bending moment). Electrosensitive materials (e.g., piezoelectric materials or electroactive polymers) can convert electricity into vibration, bending, twisting, etc. Generally, the main advantage of electro-actuated materials is their outstanding controllability almost independently of working conditions. Heat-actuated shape changes are most often achieved with shape memory polymers or alloys, but other concepts, such as liquid crystal polymers, are also researched. A common limitation of these systems is their often relatively low maximum actuation forces, but the large strains are capable of justifying their application in many cases. Pressure-actuated systems usually use inflatable pressure chambers for actuation, with which they can produce even complex deformations. However, the application of pressure is sometimes a challenge. Besides electricity, heat and pressure, light, chemicals and mechanical loading are commonly exploited to actuate non-conventional shape changes. However, mechanical actuation is by far the most researched area. The main advantage of mechanical actuation is its passive nature, as structural parts are inevitably under load during operation. This way, the system might not need any additional energy for actuation. On the other hand, this is one of its main limitations, since deformation cannot be controlled entirely independently of operating conditions. Composites have possibly the greatest potential as mechanically actuated morphing materials as they combine great tailorability of mechanical coupling behavior (e.g., bend-twist or extension-twist coupling) with outstanding specific mechanical properties. Coupled composites can make structural parts work more efficiently, especially where the optimal shapes under different loading conditions are known (e.g., wind turbine blades). Because of their industrial significance, it is expected that coupled composites will be the main focus of projects developing morphing materials in the near future. Although several publications describe the design process and performance of such composites, more emphasis has to be placed on how to overcome manufacturing challenges, which are mainly due to the (often) asymmetric layup of coupled composites. To exploit the morphing capability of composite materials, more research projects need to focus on the understanding of the mechanics of asymmetric layups and the contribution of asymmetry to hygro-thermal warping. This will hopefully serve as a good basis for designing stiff and strong shape changing materials and structures without the disadvantages of warping. The aerospace, wind energy and several other industries could greatly benefit from these results.

Author Contributions: Conceptualization, B.V. and T.C.; investigation, B.V.; writing-original draft preparation, B.V.; writing-review and editing, B.V. and T.C.; supervision, T.C.; funding acquisition, B.V. and T.C. All authors have read and agreed to the published version of the manuscript.

Funding: This work was supported by the NVKP_16-1-2016-0046, OTKA K 116070 and OTKA K 120592 projects of the National Research, Development and Innovation Office (NKFIH), the National Research, Development and Innovation Fund (TUDFO/51757/2019-ITM, Thematic Excellence Program), as well as by the Higher Education Excellence Program of the Ministry of Human Capacities in the frame of Nanotechnology research area of Budapest University of Technology and Economics (BME FIKP-NAT). Furthermore, the research was supported by the ÚNKP-18-3 New National Excellence Program of the Ministry of Human Capacities for which Bruno Vermes expresses his gratitude.

Conflicts of Interest: The authors declare no conflict of interest.

\section{References}

1. Blaiszik, B.J.; Kramer, S.L.B.; Olugebefola, S.C.; Moore, J.S.; Sottos, N.R.; White, S.R. Self-healing polymers and composites. Annu. Rev. Mater. Res. 2010, 40, 179-211. [CrossRef]

2. Kessler, M.R.; Sottos, N.R.; White, S.R. Self-healing structural composite materials. Compos. Part A Appl. Sci. Manuf. 2003, 34, 743-753. [CrossRef]

3. Di Sante, R. Fibre optic sensors for structural health monitoring of aircraft composite structures: Recent advances and applications. Sensors 2015, 15, 18666-18713. [CrossRef] [PubMed]

4. Qing, X.P.; Beard, S.J.; Kumar, A.; Ooi, T.K.; Chang, F.-K. Built-in sensor network for structural health monitoring of composite structure. J. Intell. Mater. Syst. Struct. 2007, 18, 39-49. [CrossRef]

5. Ghamsari, A.K.; Jin, Y.; Woldesenbet, E. Mechanical characterization of bucky gel morphing nanocomposite for actuating/sensing applications. Smart Mater. Struct. 2012, 21, 45007. [CrossRef] 
6. Kim, S.; Hawkes, E.; Choy, K.; Joldaz, M.; Foleyz, J.; Wood, R. Micro artificial muscle fiber using NiTi spring for soft robotics. In Proceedings of the 2009 IEEE/RSJ International Conference on Intelligent Robots and Systems, St. Louis, MO, USA, 11-15 October 2009; pp. 2228-2234.

7. Choi, W.; Akbarian, M.; Rubtsov, V.; Kim, C. Microhand with internal visual system. IEEE Trans. Ind. Electron. 2009, 56, 1005-1011. [CrossRef]

8. Motley, M.R.; Liu, Z.; Young, Y.L. Utilizing fluid-structure interactions to improve energy efficiency of composite marine propellers in spatially varying wake. Compos. Struct. 2009, 90, 304-313. [CrossRef]

9. Garcia, H.; Abdulrahim, M.; Lind, R. Roll control for a micro air vehicle using active wing morphing. In Proceedings of the AIAA Guidance, Navigation, and Control Conference and Exhibit, Austin, TX, USA, 11-14 August 2003; p. 5347.

10. Stanford, B.; Abdulrahim, M.; Lind, R.; Ifju, P. Investigation of membrane actuation for roll control of a micro air vehicle. J. Aircr. 2007, 44, 741-749. [CrossRef]

11. Boria, F.; Stanford, B.; Bowman, S.; Ifju, P. Evolutionary optimization of a morphing wing with wind-tunnel hardware in the loop. AIAA J. 2009, 47, 399-409. [CrossRef]

12. Hamilton, B.K.; Hassan, A.; Birchette, T.S.; Murrill, R.R. Composite Material for Geometric Morphing Wing. U.S. Patent 7798443, 21 September 2010.

13. Winstone, B.; Pipe, T.; Melhuish, C.; Callaway, M.; Etoundi, A.C.; Dogramadzi, S. Single motor actuated peristaltic wave generator for a soft bodied worm robot. In Proceedings of the 2016 th IEEE International Conference on Biomedical Robotics and Biomechatronics (BioRob), UTown, Singapore, 26-29 June 2016; pp. 449-456.

14. Irschik, H. A review on static and dynamic shape control of structures by piezoelectric actuation. Eng. Struct. 2002, 24, 5-11. [CrossRef]

15. Fichera, S.; Isnardi, I.; Mottershead, J.E. High-bandwidth morphing actuator for aeroelastic model control. Aerospace 2019, 6, 13. [CrossRef]

16. Yoon, B.S.; Park, J.H.; Yoon, K.J. Experimental study on control fins of a small flying vehicle using piezo-composite actuators. Adv. Compos. Mater. 2017, 26, 35-43. [CrossRef]

17. Henry, A.C.; Molinari, G.; Arrieta, A.F. Smart morphing wing: Optimization of distributed piezoelectric actuation. In Proceedings of the 25th AIAA/AHS Adaptive Structures Conference, Grapevine, TX, USA, 9-13 January 2017; pp. 1-12.

18. Jodin, G.; Scheller, J.; Duhayon, E.; Rouchon, J.F.; Braza, M. Implementation of a hybrid electro-active actuated morphing wing in wind tunnel. In Mechatronic Systems and Materials VIII; Solid State Phenomena; Trans Tech Publications: Stafa-Zurich, Switzerland, 2017; Volume 260, pp. 85-91.

19. Bye, D.; McClure, P. Design of a morphing vehicle. In Proceedings of the 48th AIAA/ASME/ASCE/AHS/ASC Structures, Structural Dynamics, and Materials Conference, Honolulu, HI, USA, 23-26 April 2007; p. 1728.

20. Ahmed, M.R.; Abdelrahman, M.M.; ElBayoumi, G.M.; ElNomrossy, M.M. Optimal wing twist distribution for roll control of MAVs. Aeronaut. J. 2011, 115, 641-649. [CrossRef]

21. Nabawy, M.R.A.; Parslew, B.; Crowther, W.J. Dynamic performance of unimorph piezoelectric bending actuators. Proc. Inst. Mech. Eng. Part I J. Syst. Control Eng. 2014, 229, 118-129. [CrossRef]

22. Nabawy, M.R.A.; Crowther, W.J. Dynamic electromechanical coupling of piezoelectric bending actuators. Micromachines 2016, 7, 12. [CrossRef]

23. Keplinger, C.; Li, T.; Baumgartner, R.; Suo, Z.; Bauer, S. Harnessing snap-through instability in soft dielectrics to achieve giant voltage-triggered deformation. Soft Matter 2012, 8, 285-288. [CrossRef]

24. Kornbluh, R.D.; Pelrine, R.; Pei, Q.; Oh, S.; Joseph, J. Ultrahigh strain response of field-actuated elastomeric polymers. In Proceedings of the Smart Structures and Materials 2000: Electroactive Polymer Actuators and Devices (EAPAD), Newport Beach, CA, USA, 6-8 March 2000; Volume 3987, pp. 3914-3987.

25. Duduta, M.; Hajiesmaili, E.; Zhao, H.; Wood, R.J.; Clarke, D.R. Realizing the potential of dielectric elastomer artificial muscles. Proc. Natl. Acad. Sci. USA 2019, 116, 2476-2481. [CrossRef]

26. Whiter, R.A.; Boughey, C.; Smith, M.; Kar-Narayan, S. Mechanical energy harvesting performance of ferroelectric polymer nanowires grown via template-wetting. Energy Technol. 2018, 6, 928-934. [CrossRef]

27. Heath, C.J.C.; Bond, I.P.; Potter, K.D. Electrostatic adhesion for added functionality of composite structures. Smart Mater. Struct. 2016, 25, 25016. [CrossRef]

28. Bergamini, A.; Christen, R.X.; Maag, B.; Motavalli, M. A sandwich beam with electrostatically tunable bending stiffness. Smart Mater. Struct. 2006, 15, 678-686. [CrossRef] 
29. Heath, C.J.C.; Bond, I.P.; Potter, K.D. Interlocking electro-bonded laminates. J. Intell. Mater. Syst. Struct. 2017, 28, 1524-1529. [CrossRef]

30. Testoni, O.; Bergamini, A.; Bodkhe, S.; Ermanni, P. Smart material based mechanical switch concepts for the variation of connectivity in the core of shape-adaptable sandwich panels. Smart Mater. Struct. 2019, 28, 25036. [CrossRef]

31. Tabata, O.; Konishi, S.; Cusin, P.; Ito, Y.; Kawai, F.; Hirai, S.; Kawamura, S. Micro fabricated tunable bending stiffness devices. Sens. Actuators A Phys. 2001, 89, 119-123. [CrossRef]

32. Kim, J.; Yun, S.-R.; Deshpande, S. Synthesis, characterization and actuation behavior of polyaniline-coated electroactive paper actuators. Polym. Int. 2007, 56, 1530-1536. [CrossRef]

33. Beregoi, M.; Evanghelidis, A.; Diculescu, V.C.; Iovu, H.; Enculescu, I. Polypyrrole actuator based on electrospun micro-ribbons. ACS Appl. Mater. Interfaces 2017, 9, 38068-38075. [CrossRef] [PubMed]

34. Watanabe, M.; Imaizumi, S.; Yasuda, T.; Kokubo, H. Ion gels for ionic polymer actuators. In Soft Actuators: Materials, Modeling, Applications, and Future Perspectives; Springer: New York, NY, USA, 2014; pp. 141-156.

35. Kruusamäe, K.; Sugino, T.; Asaka, K. Measuring blocking force to interpret ionic mechanisms within bucky-gel actuators. In Proceedings of the Electroactive Polymer Actuators and Devices (EAPAD), San Diego, CA, USA, 9-12 March 2015; Volume 9430, pp. 1-9.

36. Ogawa, N.; Hashimoto, M.; Takasaki, M.; Hirai, T. Characteristics evaluation of PVC gel actuators. In Proceedings of the 2009 IEEE/RSJ International Conference on Intelligent Robots and Systems, St. Louis, MO, USA, 11-15 October 2009; pp. 2898-2903.

37. Jiang, H.; Fan, L.; Yan, S.; Li, F.; Li, H.; Tang, J. Tough and electro-responsive hydrogel actuators with bidirectional bending behavior. Nanoscale 2019, 11, 2231-2237. [CrossRef]

38. Davidson, J.R.; Krebs, H.I. An electrorheological fluid actuator for rehabilitation robotics. IEEE/ASME Trans. Mechatron. 2018, 23, 2156-2167. [CrossRef]

39. Grad, P. Against the flow [smart fluids]. Eng. Technol. 2006, 1, 34-37. [CrossRef]

40. Taghavi, M.; Helps, T.; Rossiter, J. Electro-ribbon actuators and electro-origami robots. Sci. Robot. 2018, 3, eaau9795. [CrossRef]

41. Arnaud, A.; Monfray, S.; Boughaleb, J.; Trioux, E.; Boeuf, F.; Cugat, O.; Skotnicki, T. Modeling of the thermo-mechanical efficiency of the bimetal strip heat engines. J. Phys. Conf. Ser. 2014, 557, 12015. [CrossRef]

42. Boisseau, S.; Despesse, G.; Monfray, S.; Puscasu, O.; Skotnicki, T. Semi-flexible bimetal-based thermal energy harvesters. Smart Mater. Struct. 2013, 22, 25021. [CrossRef]

43. Hartl, D.J.; Lagoudas, D.C. Aerospace applications of shape memory alloys. Proc. Inst. Mech. Eng. Part G J. Aerosp. Eng. 2007, 221, 535-552. [CrossRef]

44. Shaw, J.; Churchill, C.; Triantafyllidis, N.; Michailidis, P.; Grummon, D.; Foltz, J. Shape memory alloy honeycombs: Experiments \& simulation. In Proceedings of the 48th AIAA/ASME/ASCE/AHS/ASC Structures, Structural Dynamics, and Materials Conference, Honolulu, HI, USA, 23-26 April 2007; American Institute of Aeronautics and Astronautics: Reston, VA, USA, 2007; p. 1739.

45. Ogawa, Y.; Ando, D.; Sutou, Y.; Koike, J. A lightweight shape-memory magnesium alloy. Science 2016, 353, 368-370. [CrossRef] [PubMed]

46. Lu, H.; Liang, F.; Yao, Y.; Gou, J.; Hui, D. Self-assembled multi-layered carbon nanofiber nanopaper for significantly improving electrical actuation of shape memory polymer nanocomposite. Compos. Part B Eng. 2014, 59, 191-195. [CrossRef]

47. Lendlein, A.; Jiang, H.; Jünger, O.; Langer, R. Light-induced shape-memory polymers. Nature 2005, 434, 879-882. [CrossRef]

48. Lendlein, A.; Langer, R. Biodegradable, elastic shape-memory polymers for potential biomedical applications. Science 2002, 296, 1673-1676. [CrossRef]

49. Voit, W.; Ware, T.; Dasari, R.R.; Smith, P.; Danz, L.; Simon, D.; Barlow, S.; Marder, S.R.; Gall, K. High-strain shape-memory polymers. Adv. Funct. Mater. 2010, 20, 162-171. [CrossRef]

50. Humbeeck, J. Van Non-medical applications of shape memory alloys. Mater. Sci. Eng. A 1999, 273-275, 134-148. [CrossRef]

51. Maksimkin, A.V.; Kaloshkin, S.D.; Zadorozhnyy, M.V.; Senatov, F.S.; Salimon, A.I.; Dayyoub, T. Artificial muscles based on coiled UHMWPE fibers with shape memory effect. Express Polym. Lett. 2018, 12, $452-461$. [CrossRef] 
52. Zhang, C.-S.; Ni, Q.-Q. Bending behavior of shape memory polymer based laminates. Compos. Struct. 2007, 78, 153-161. [CrossRef]

53. Cho, J.W.; Kim,J.W.; Jung, Y.C.; Goo, N.S. Electroactive shape-memory polyurethane composites incorporating carbon nanotubes. Macromol. Rapid Commun. 2005, 26, 412-416. [CrossRef]

54. Ohm, C.; Brehmer, M.; Zentel, R. Liquid crystalline elastomers as actuators and sensors. Adv. Mater. 2010, 22, 3366-3387. [CrossRef] [PubMed]

55. Wermter, H.; Finkelmann, H. Liquid crystalline elastomers as artificial muscles. e-Polymers 2001, 1, 1-13. [CrossRef]

56. Yang, H.; Buguin, A.; Taulemesse, J.-M.; Kaneko, K.; Méry, S.; Bergeret, A.; Keller, P. Micron-sized main-chain liquid crystalline elastomer actuators with ultralarge amplitude contractions. J. Am. Chem. Soc. 2009, 131, 15000-15004. [CrossRef] [PubMed]

57. Ward, M.A.; Georgiou, T.K. Thermoresponsive polymers for biomedical applications. Polymers 2011, 3, 1215-1242. [CrossRef]

58. Na, J.-H.; Evans, A.A.; Bae, J.; Chiappelli, M.C.; Santangelo, C.D.; Lang, R.J.; Hull, T.C.; Hayward, R.C. Programming reversibly self-folding origami with micropatterned photo-crosslinkable polymer trilayers. Adv. Mater. 2015, 27, 79-85. [CrossRef]

59. Ercole, F.; Davis, T.P.; Evans, R.A. Photo-responsive systems and biomaterials: Photochromic polymers, light-triggered self-assembly, surface modification, fluorescence modulation and beyond. Polym. Chem. 2010, 1, 37-54. [CrossRef]

60. Fang, L.; Chen, S.; Fang, T.; Fang, J.; Lu, C.; Xu, Z. Shape-memory polymer composites selectively triggered by near-infrared light of two certain wavelengths and their applications at macro-/microscale. Compos. Sci. Technol. 2017, 138, 106-116. [CrossRef]

61. Li, Z.; Zhang, X.; Wang, S.; Yang, Y.; Qin, B.; Wang, K.; Xie, T.; Wei, Y.; Ji, Y. Polydopamine coated shape memory polymer: Enabling light triggered shape recovery, light controlled shape reprogramming and surface functionalization. Chem. Sci. 2016, 7, 4741-4747. [CrossRef]

62. Jiang, H.Y.; Kelch, S.; Lendlein, A. Polymers move in response to light. Adv. Mater. 2006, 18, 1471-1475. [CrossRef]

63. Zeng, H.; Wasylczyk, P.; Parmeggiani, C.; Martella, D.; Burresi, M.; Wiersma, D.S. Light-fueled microscopic walkers. Adv. Mater. 2015, 27, 3883-3887. [CrossRef] [PubMed]

64. Wei, J.; Yu, Y. Photodeformable polymer gels and crosslinked liquid-crystalline polymers. Soft Matter 2012, 8, 8050-8059. [CrossRef]

65. De Volder, M.; Ceyssens, F.; Reynaerts, D.; Puers, R. A PDMS lipseal for hydraulic and pneumatic microactuators. J. Micromech. Microeng. 2007, 17, 1232-1237. [CrossRef]

66. De Volder, M.; Reynaerts, D. Pneumatic and hydraulic microactuators: A review. J. Micromech. Microeng. 2010, 20, 43001. [CrossRef]

67. Ok, J.; Lu, Y.; Kim, C.C. Pneumatically driven microcage for microbe manipulation in a biological liquid environment. J. Microelectromech. Syst. 2006, 15, 1499-1505. [CrossRef]

68. Ikeuchi, M.; Ikuta, K. Development of pressure-driven micro active catheter using membrane micro emboss following excimer laser ablation (MeME-X) process. In Proceedings of the 2009 IEEE International Conference on Robotics and Automation, Kobe, Japan, 12-17 May 2009; pp. 4469-4472.

69. Yang, X.; Tai, Y.-C.; Ho, C.-M. Micro bellow actuators. In Proceedings of the International Solid State Sensors and Actuators Conference (Transducers '97), Chicago, IL, USA, 16-19 June 1997; Volume 1, pp. 45-48.

70. De Volder, M.; Moers, A.J.M.; Reynaerts, D. Fabrication and control of miniature McKibben actuators. Sens. Actuators A Phys. 2011, 166, 111-116. [CrossRef]

71. Song, S.; Sitti, M. Soft grippers using micro-fibrillar adhesives for transfer printing. Adv. Mater. 2014, 26, 4901-4906. [CrossRef]

72. Gorissen, B.; Vincentie, W.; Al-Bender, F.; Reynaerts, D.; De Volder, M. Modeling and bonding-free fabrication of flexible fluidic microactuators with a bending motion. J. Micromech. Microeng. 2013, 23, 45012. [CrossRef]

73. Yang, D.; Mosadegh, B.; Ainla, A.; Lee, B.; Khashai, F.; Suo, Z.; Bertoldi, K.; Whitesides, G.M. Buckling of elastomeric beams enables actuation of soft machines. Adv. Mater. 2015, 27, 6323-6327. [CrossRef]

74. Gorissen, B.; Chishiro, T.; Shimomura, S.; Reynaerts, D.; De Volder, M.; Konishi, S. Flexible pneumatic twisting actuators and their application to tilting micromirrors. Sens. Actuators A Phys. 2014, 216, 426-431. [CrossRef] 
75. Kang, H.-W.; Lee, I.H.; Cho, D.-W. Development of a micro-bellows actuator using micro-stereolithography technology. Microelectron. Eng. 2006, 83, 1201-1204. [CrossRef]

76. Shanmuganathan, K.; Capadona, J.R.; Rowan, S.J.; Weder, C. Biomimetic mechanically adaptive nanocomposites. Prog. Polym. Sci. 2010, 35, 212-222. [CrossRef]

77. Capadona, J.R.; Shanmuganathan, K.; Tyler, D.J.; Rowan, S.J.; Weder, C. Stimuli-responsive polymer nanocomposites inspired by the sea cucumber dermis. Science 2008, 319, 1370-1374. [CrossRef] [PubMed]

78. Chen, J.-K.; Chang, C.-J. Fabrications and applications of stimulus-responsive polymer films and patterns on surfaces: A review. Materials 2014, 7, 805-875. [CrossRef] [PubMed]

79. Liu, Y.; Xu, B.; Sun, S.; Wei, J.; Wu, L.; Yu, Y. Humidity- and photo-induced mechanical actuation of cross-linked liquid crystal polymers. Adv. Mater. 2017, 29, 1604792. [CrossRef]

80. Poonsong, P. Design and Analysis of Multi-Section Variable Camber Wing. Master's Thesis, University of Maryland, College Park, MD, USA, 2004.

81. Thumthae, C.; Chitsomboon, T. Optimal angle of attack for untwisted blade wind turbine. Renew. Energy 2009, 34, 1279-1284. [CrossRef]

82. Ajaj, R.M.; Friswell, M.I.; Dettmer, W.G.; Allegri, G.; Isikveren, A.T. Conceptual modeling of an adaptive torsion wing structure. In Proceedings of the 52nd AIAA/ASME/ASCE/AHS/ASC Structures, Structural Dynamics and Materials Conference, Denver, CO, USA, 4-7 April 2011; p. 1883.

83. Ajaj, R.M.; Friswell, M.I.; Smith, D.D.; Allegri, G.; Isikveren, A.T. Roll control of a UAV using an adaptive torsion structure. In Proceedings of the 52nd AIAA/ASME/ASCE/AHS/ASC Structures, Structural Dynamics and Materials Conference, Denver, CO, USA, 4-7 April 2011; p. 1834.

84. Runge, J.B.; Osmont, D.; Ohayon, R. Twist control of airfoils using a "reactive" method. In Proceedings of the SPIE Smart Structures and Materials + Nondestructive Evaluation and Health Monitoring, San Diego, CA, USA, 7-11 March 2010; Volume 7643, pp. 764305-764310.

85. Runge, J.-B.; Osmont, D.; Ohayon, R. Twist control of aerodynamic profiles by a reactive method (experimental results). J. Intell. Mater. Syst. Struct. 2012, 24, 908-923. [CrossRef]

86. Hufenbach, W.; Gude, M.; Kroll, L. Design of multistable composites for application in adaptive structures. Compos. Sci. Technol. 2002, 3538, 2201-2207. [CrossRef]

87. Daynes, S.; Diaconu, C.G.; Potter, K.D.; Weaver, P.M. Bistable prestressed symmetric laminates. J. Compos. Mater. 2009, 44, 1119-1137. [CrossRef]

88. Peeters, L.J.B.; Powell, P.C.; Warnet, L. Thermally-induced shapes of unsymmetric laminates. J. Compos. Mater. 1996, 30, 603-626. [CrossRef]

89. Daynes, S.; Potter, K.D.; Weaver, P.M. Bistable prestressed buckled laminates. Compos. Sci. Technol. 2008, 68, 3431-3437. [CrossRef]

90. Daynes, S.; Weaver, P.M.; Potter, K.D. Aeroelastic study of bistable composite airfoils. J. Aircr. 2009, 46, 6-10. [CrossRef]

91. Dai, F.; Li, H.; Du, S. Design and analysis of a tri-stable structure based on bi-stable laminates. Compos. Part A 2012, 43, 1497-1504. [CrossRef]

92. York, C. Unified approach to the characterization of coupled composite laminates configurations: Hygrothermally curvature-stable configurations. Int. J. Struct. Integr. 2012, 2, 406-436. [CrossRef]

93. York, C.B. On extension-shearing coupled laminates. Compos. Struct. 2015, 120, 472-482. [CrossRef]

94. York, C.B. Extension-twist coupled laminates for aero-elastic compliant blade design. In Proceedings of the 53rd AIAA/ASME/ASCE/AHS/ASC Structures, Structural Dynamics and Materials Conference, Honolulu, HI, USA, 23-26 April 2012.

95. York, C.B. On bending-twisting coupled laminates. Compos. Struct. 2017, 160, 887-900. [CrossRef]

96. Li, J.; Li, D. Extension-shear coupled laminates with immunity to hygro-thermal shearing distortion. Compos. Struct. 2015, 123, 401-407. [CrossRef]

97. Ward, E.; Chopra, I.; Datta, A. Rotation-frequency-driven extension-torsion coupled self-twisting rotor blades. J. Aircr. 2018, 55, 1929-1941. [CrossRef]

98. Haynes, R.A. New families of hygrothermally stable composite laminates with optimal extension-twist coupling. AIAA J. 2010, 48, 2954-2961. [CrossRef]

99. Lin, C.-C.; Lee, Y.-J.; Hung, C.-S. Optimization and experiment of composite marine propellers. Compos. Struct. 2009, 89, 206-215. [CrossRef] 
100. Liu, Z.; Young, Y.L. Utilization of bend-twist coupling for performance enhancement of composite marine propellers. J. Fluids Struct. 2009, 25, 1102-1116. [CrossRef]

101. Shakya, P.; Sunny, M.R.; Maiti, D.K. A parametric study of flutter behavior of a composite wind turbine blade with bend-twist coupling. Compos. Struct. 2019, 207, 764-775. [CrossRef]

102. Drummond, M. Magneride for Mustang. 2019. Available online: https://www.cjponyparts.com/resources/ magneride-suspensions (accessed on 18 November 2019).

103. Andersen, G.; Cowan, D.; Piatak, D. Aeroelastic modeling, analysis and testing of a morphing wing structure. In Proceedings of the 48th AIAA/ASME/ASCE/AHS/ASC Structures, Structural Dynamics, and Materials Conference, Honolulu, HI, USA, 23-26 April 2007; p. 1734.

104. Lin, J.; Dover Lp, I.; Fang, H.; Im, E.; Quijano, U. Concept study of a 35-m spherical reflector system for NEXRAD in space application. In Proceedings of the 47th AIAA/ASME/ASCE/AHS/ASC Structures, Structural Dynamics, and Materials Conference, Newport, RI, USA, 1-4 May 2006; Volume 1.

105. Richard, C. "Bend-Twist Coupling" Tests Begin. 2018. Available online: https://www.windpowermonthly. com/article/1520855/bend-twist-coupling-tests-begin (accessed on 20 October 2019).

106. Chandler, D.L. MIT and NASA Engineers Demonstrate a New Kind of Airplane Wing. 2019. Available online: http://news.mit.edu/2019/engineers-demonstrate-lighter-flexible-airplane-wing-0401 (accessed on 13 November 2019).

(C) 2020 by the authors. Licensee MDPI, Basel, Switzerland. This article is an open access article distributed under the terms and conditions of the Creative Commons Attribution (CC BY) license (http://creativecommons.org/licenses/by/4.0/). 